\title{
The cultural nature of tephra: 'problematic' ecofacts and artifacts and the Barú volcano, Panamá
}

\author{
Karen Holmberg
}

New York University, Environmental Studies

kgh11@columbia.edu

\section{Introduction}

If geoarchaeology is a nexus science (Dugmore and Newton, 2012; Nicoll and Murphy, 2014), then tephra can be seen as a nexus material via its importance in a growing number of scientific subfields. Tephra studies are increasingly important components of Quaternary research and provide a unique means to address palaeoenvironmental and archaeological chronologies (Lowe, 2011). The precise relationship between key volcanic eruptions and the archaeological and environmental record can be highly problematic, however, even for heavily studied volcanic events such as the Bronze Age eruption of Santorini/Thera (e.g., Friedrich et al., 2006; Manning, 1999; Manning et al., 2006; Pearson et al., 2005). For lesser studied contexts, such as those of Central America, the challenges are compounded. The accumulation of further data in such contexts is requisite for a multidisciplinary consideration of volcanic eruption and materials.

This paper presents data from archaeological stratigraphy and lacustrine core samples containing tephra from the Barú volcano in western Panamá. The discussion seeks to refine the understanding of medial tephra deposits near Barú in relation to the eruption history indicated by geological, palaeoecological, and archaeological data. A primary goal of the study was the identification and description of tephra from major Barú eruptions encountered in archaeological contexts by their lithology, stratigraphic position, and mineralogy. Innovative new technologies that are more cost-efficient than geochemical fingerprinting and permit the creation of a visual archive of tephra particles are suggested as possible ways to further examine and identify volcanic materials from Central American archaeological sites.

\subsection{Central American tephrochronology}


Relative to the well-developed tephrochronologies of Iceland, New Zealand, and elsewhere, Latin American tephras have received a lesser degree of attention. This is disadvantageous, as tephra can provide important horizon markers for the post late-glacial history of the area. A majority of the foundational Latin American tephrochronology studies are in México (Gonzalez et al.; Luhr et al., 2010; Newton and Metcalfe, 1999; Newton et al., 2005b; Rabek et al., 1985), and central Mexico is the only context from the Americas represented by data in Tephrabase (www.tephrabase.org). The southern Andes and Patagonia have garnered a fair number of recent tephrochronology studies (e.g., Bertrand et al., 2008; Daga et al., 2014; Fontijn et al., 2014; Haberzettl et al., 2007; Kilian et al., 2003; Watt et al., 2011) while the central Andes (e.g., Breitkreuz et al., 2014) and northern Andes (e.g., Hansen et al., 2003; Le Pennec et al., 2008; Rodbell et al., 2002; Tonneijck et al., 2008) are also becoming better represented in the published literature. Central America, by comparison, has a paucity of recent tephrochronology studies despite its highly volcanic context. The majority of Central American tephra studies are of Arenal volcano in Costa Rica (e.g., Alvarado et al., 2006; Bolge et al., 2006; Cole et al., 2005; Soto and Alvarado, 2006) or other volcanoes and offshore deposits (e.g.; Clift et al., 2005; Shaw et al., 2006). Tephrochronology studies of Ilopongo volcano in El Salvador, which stem from the archaeological work of Payson Sheets, provide an important example of recent Central American tephrochronology (Dull et al., 2001; Mehringer et al., 2005).

\section{Regional setting: Barú volcano}

\subsection{Geological setting of Barú}

The Barú volcano, located near a complex junction of seismically active tectonic plates, forms the southern terminus of the arc of Central American volcanoes created by the subducting Cocos plate. The Barú cone volcano covers $280 \mathrm{~km}^{2}$ and represents an overlapping series of pyroclastic flows, lahars, and lava flows (Sherrod et al., 2007: 10). Barú's current form, as estimated from 90-m resolution Shuttle Radar Topography Mission (SRTM) data, has a volume of roughly 140x $\mathrm{km}^{3}$ and an area of approximately $394 \mathrm{~km}^{2}$ (Van Wyk de Vries et al., 2007: 135). The palimpsest of forms, flows, and deposits prevent the earliest part of the volcano from being accessible or dateable. 
Barú was the site of what was potentially the largest volcano debris avalanche in Central America, resulting in a $6 \times 10 \mathrm{~km}$ horseshoe-shaped caldera that is breached to the west (Siebert

et al., 2006; Siebert et al., 2004). The more eroded western flank is characteristic of isthmian area volcanoes due to the higher rainfall on the Caribbean-side slopes (Van Wyk de Vries et al., 2007: 128). The large amount of water from both rainfall and streams makes lahars a common phenomenon of Barú eruptions, and a $\sim 40 \mathrm{~km}$ wide radial lahar extends across the forearc of western Panamá (Morell et al., 2008).

The <12.4 ka maximum date (IRHE, 1987) estimated during geothermal analysis and the 2860 +/- 50 BP date from the lowest sediment layer of a lake core examined by Behling (2000) may provide rough bounding dates for the collapse in the assessment of Siebert et al. (2006). Sherrod et al. (2007: 4, 13), however, believe that the avalanche occurred earlier than the 8,740 +/- 90 14C BP (9540 cal BP) date of silt found below a terrace where a redirection of the Río Chiriquí Viejo cut into an alluvial fan and date the debris avalanche at more than $50 \mathrm{ka}$ in age.

\subsection{The role and timing of Barú eruptions during human occupation}

Evidence from lake-sediment cores in central and eastern Panamá (La Yeguada and Cana) point to extensive forest clearance by roughly 7000 BP (Cooke, 2005: 140-42; Piperno, 2006). This clearance was directly related to the dispersal and intensification of food production. Many of the tropical plants that subsequently became New World staples - such as maize (Zea mays), cassava (Manihot esculenta), yams (Discorea spp.) and squash (Cucurbita) - were being widely planted in Panamá by the Late Preceramic period of 7000-4500 BP (Dickau et al., 2007; Piperno et al., 2000a; Piperno et al., 2000b). The use of fire and clearance of vegetation for agriculture related to permanent settlements is evident in highland western Panamá, near the Barú volcano, after 2860 BP (Behling, 2000; Cooke, 2005).

The United States Geological Survey (USGS) Open File Report 2007-1401 by Sherrod et al. (2007) provides the most syncretic and accurate published assessment of Barú's eruption history to date. Using data from paleosols and eleven new AMS dates, Sherrod et al. (2007) synthesize data from palaeoecological studies and archaeological research to suggest the occurrence of four eruptions during the period for which archaeological evidence suggests permanent settlements in the Barú region. A 400-500 year dormancy separates the current landscape from the first and most recent episode, which Sherrod et al. (2007) place between 420- 
540 cal BP. Roughly 250 years of dormancy divide episode one and episode two, which is undated. Another roughly 250 year dormancy divides episodes two and three, which is interpreted between 690-950 cal BP. A roughly 230 to 620 year dormancy then separates their episodes three and four, interpreted to have occurred sometime between 1180-1310 cal BP.

Sherrod et al. (2007) do not accept the radiocarbon date used by Linares and Ranere (1980) to propose that an AD 600 eruption of Barú prompted significant settlement changes in the region and depopulation of the Barú area. In tandem with Anchukaitis and Horn (2005), the USGS researchers agree that the radiocarbon date from the Linares and Ranere (1980) project (I$7236 ; 740 \pm 150$ BP uncalibrated date, AD 988-1450 calibrated calendar year, $2 \delta$ ) is associated with volcanism. The large analytical error of this date, however, makes its attribution to a particular eruption too uncertain (Sherrod et al., 2007: 17). The Sherrod et al (2007) assessment accepts all three AMS dates used to date tephra layers in a lake-sediment core from Behling (2000). The USGS assessment also accepts AMS dates utilized by Clement and Horn (2001) and Anchukaitis and Horn (2005) to date lake-sediment cores containing Barú tephra. The three palaeoecological studies, which examine the presence of maize (Zea mays) pollen and palynological evidence for forest burning or regeneration, link only the most recent eruption of Barú to significant decreases in human occupation of the area.

\section{Material and methods: examining Barú tephra}

Tephra formed an important data component in the Linares and Ranere (1980) interpretations of how volcanism impacted pre-Columbian populations, though minimal description of the tephra was published. Dahlin (1980: 276-7) describes tephra from the Barriles site as follows:

Throughout the survey area the culture-bearing strata are capped by a more or less thick layer of pumice with a contemporary humic layer on top.... Using the sondage technique enabled us to tentatively assess the variable effects of the pumice fall. In recording the amount, size, and angularity of the pumice particles and the nature of their deposition at any and all locations within the survey area, we were able to identify the source of the pumice as Volcán Barú and conclude that it affected the entire survey area.

Dahlin (1980) does not provide details regarding how the tephra was sourced to Barú and morphological data are not included. Linares et al. (1975) describe the uppermost tephra layer as 
'part pumice, part soil; medium yellow pumice', which Sherrod et al (2007: 29) interpret as 'slightly weathered pumice lapilli admixed with soil...' Rosenthal (1980: 290-1) provides stratigraphic descriptions and profile drawings for Barriles that place a talpetate, or 'yellow brown, hard-packed volcanic ash' roughly $90 \mathrm{~cm}$ below the surface, with 'pockets of black clay and yellow weathered pumice pieces' (Cut 1)(ibid.). These were interpreted as fluvial deposits. In another stratigraphic face (Cut 2) the talpetate is topped with a 'yellow weathered pumice and heavy deposit of sherds', marking an admixture of volcanic and human materials (ibid.). Above this layer 'an intervening stratum of black sediment which is mottled with white' is noted (ibid.), though whether this represents a white pumice or some other material is impossible to determine as no further description is provided. Especially in light of recent advances and interest in tephrochronology the examination of tephra in Barú area archaeological contexts, begun in the Adaptive Radiations study by Linares and Ranere (1980), merits renewed inquiry.

\subsection{Tephra included in this study}

\subsubsection{Survey area}

Pyroclastic flows and lahars from multiple eruptive events deposited heavier materials predominantly on the west side of the Barú crater due to a breach in the crater wall caused by the debris avalanche described in section 2.1 of this paper. Light-weight and pumice-rich lapilli and ash, however, are found on both sides of the crater. For this reason sampling for the present study focused upon these juvenile materials.

The primary area of tephra collection and archaeological fieldwork was a roughly $40 \mathrm{~km}^{2}$ area east of the Barú crater along the Rio Caldera. Surface survey, shovel test pits $(n=297)$, and $1 \times 1 \mathrm{~m}$ trowel-excavated test units $(\mathrm{n}=34)$ yielded artifacts, tephra, carbon samples, and stratigraphic data from an estimated $4.08 \mathrm{~km}^{2}$, or roughly a $10 \%$ sample of this area. Survey areas ranged from 920-1680 m elevation. Shovel test pits averaged $40 \mathrm{~cm}$ in diameter and $70 \mathrm{~cm}$ depth and were spaced every $10 \mathrm{~m}$ upon north-bearing transects.

Survey areas were divided into three categories by their distance from the Barú crater using concentric circles to provide heuristic estimates of tephra fall distributions. These tephra fall ranges extend those already defined by the USGS for the primary tephra falls (Sherrod et al., 2007). USGS isothickness lines for expected $10 \mathrm{~cm}$ and $3 \mathrm{~cm}$ tephra fall radii were placed 
roughly $5 \mathrm{~km}$ and $6.5 \mathrm{~km}$ from the main crater. For this study, additional circles of hypothetical fallout lines were placed at $9 \mathrm{~km}, 13 \mathrm{~km}$, and $20 \mathrm{~km}$ radii from the main crater.

\subsubsection{Assumptions of the study}

A primary assumption in this study is that all tephra in the Barú vicinity came from Barú eruptions. In this I join a number of other researchers (Anchukaitis and Horn, 2005; Behling, 2000; Cooke et al., 2003: 25; Linares and Ranere, 1980). It is possible that large-scale eruptions (such as the 1835 eruption of Cosigüina in Nicaragua, which deposited ash throughout most of Central America) could complicate the tephra record but this was deemed unlikely. Geochemical differences between Central American Quaternary volcanoes vary widely (Johnston and Thorkelson, 1997: 469; although see Newton et al., 2007: 738; Zeilinga de Boer et al., 1988: 279). Thus, another assumption of this project is that separate eruptions of Barú could potentially be distinctive enough to provide a chronostratigraphic marker without geochemical analyses. While the complexity of tephra preservation means that tephra thickness or stratigraphic locations might vary, the expectation was that increased distance from the volcano summit would correspond to decreased tephra presence in archaeological stratigraphy.

\subsubsection{Examining medial range tephra in the archaeological stratigraphy}

Repeated blankets of tephra spread more than $100 \mathrm{~km}$ downwind from Barú in its past eruptions, though most deposits are found with a 10-20 cm thickness at a medial distance of 10$15 \mathrm{~km}$ downwind (Sherrod et al., 2007: 5 and Figure 4). These medial tephras formed the focus

of fieldwork because they were most likely to contain the highest amount of juvenile material, compared to distal or proximal deposits, and could be potentially identified and correlated in bulk samples by mineral analysis and shard morphology. Even within very small areas, volcanic materials from a single eruption can show a high variability in Central American archaeological contexts (Sheets, 1979). This proved to be the case in the Barú context.

Tephra samples were collected from each archaeological context within the $40 \mathrm{~km}^{2}$ survey area on the eastern flanks of Barú. Most archaeological stratigraphy evidenced two tephra layers with expectedly inconsistent depths and locations. As three tephra-bearing eruptions events are proposed by Sherrod et al. (2007) during prehistoric settlement of the Barú area, one 
tephra layer - though not necessarily the same layer in each context - is absent in all of the archaeological deposits from the eastern flank of Barú as a visible stratigraphic layer.

The focus of tephra analyses shifted, therefore, to establishing a baseline to correlate the tephra in a way that could be replicated by other archaeologists without the considerable expense of geochemical analyses. To distill the tephra characteristics found in the region into a simple schema, a very restrained number of samples from the most ideal contexts was deemed useful in deference to the principle of parsimony. The selected samples came from the following sources:

1) Barriles archaeological site. This site became an important regional center after maize agriculture permitted intensive occupation in the highlands of western Panamá. The site provided the tephra and radiocarbon date that Linares and Ranere (1980) used to propose a catastrophic eruption at AD 600 that transformed settlement patterns in western Panamá.

2) Lake-sediment cores. Tephra layers can be best preserved in marine or lacustrine environments (Horn, 2007: 439; Kutterolf et al., 2007; Newton et al., 2005a; Schiff et al., 2008; Zolitschka et al., 2006). Tephra samples were therefore taken from two lake-sediment cores held at the Smithsonian Tropical Research Institute (STRI) - one east of the Barú crater and one west - to provide a record of representative sediments in the area. One of these cores was utilized by the USGS to provide dates for prior eruptions of Barú (Behling 2000; noted in section 2.2) and one was taken from a lake near the survey area that has associated but unpublished AMS dates.

\subsection{Tephra sample analyses}

Ten discrete tephra samples, four from each of the lake-sediment cores and two from the site of Barriles, were exposed to a series of ten minute sonic baths in de-ionized water, dried under a heat lamp, and washed with acetone. A Nikon SMZ-2T binocular microscope at 1.5x magnification with a fiber optic light was used to record the compositions and characteristics of each sample and at 6x magnification to define and photograph the vesicularity of clasts.

Three obvious layers were present in the lake-sediment cores, though only two layers were present in the Barriles archaeological stratigraphy (see Figure 4). As noted in section 2.2 of 
this paper, the USGS report by Sherrod et al. (2007) does posit a fourth eruption during the period of intensive Holocene occupation of the Barú highlands. The paleosol that evidenced this eruption was located $4.6 \mathrm{~km}$ west of the Barú summit, hence in a proximal location, and is comprised solely by pyroclastic surge and surge fallout with no associated tephra fall so no representation of this volcanic event was expected.

\section{Results}

The samples varied most significantly in percentages and colors of juvenile clasts, hornblende (a black, crystalline formation with a 60-120 cleavage common in intermediate magmas), biotite (black crystal sheets), and feldspar (white crystalline formations, likely either sanidine or plagioclase). A preliminary description of the samples can be found in Holmberg (2007) and is not repeated in this paper, which represents more complete and recent interpretations of Barú tephra and eruption history. A summary of tephra sample characteristics can be found in Table 1.

\subsection{The Volcán lake-sediment core tephra samples}

The first sample set is comprised of tephra from the Laguna Volcán lake-sediment core detailed in Behling (2000). Laguna Volcán is roughly $16 \mathrm{~km}$ southwest of the Barú crater. While Behling (2000) believed the lake to be a volcanic crater, Sherrod et al. (2007) instead interpret it as a pond formed within a closed depression on the surface of the avalanche deposit created when the Barú crater wall collapsed. The core contained three distinct tephras, with the lowest divided into two phases.

\subsubsection{Uppermost and most recent sample}

The uppermost sample appears coarse and light gray in macroscopic examination, but the juvenile matrix became pure white and glassy when washed and viewed under the microscope. The composition is predominantly feldspar $(0.5-1.5 \mathrm{~mm})$ and loose black hornblende chunks $(0.5-2 \mathrm{~mm})$ with some very white juvenile clasts $(1.5-6 \mathrm{~mm})$ and some gray juvenile and hornblende inclusions. The deposit is very 'clean' and shows a mafic crystal size. Many amphibole and green crystal (olivine or pyroxene) are present in the juvenile material and some unusual rose crystal and biotite particles are present. Clasts at 6x magnification show some irregular pitting and tunnels. 


\subsubsection{Middle sample}

The middle sample from the Volcán core is comprised of light yellow-white and gray juvenile clasts $(1-4 \mathrm{~mm})$ with small hornblende inclusions $(0.25 \mathrm{~mm})$ and some loose hornblende chunks $(\sim 1 \mathrm{~mm})$. There is a higher percentage of ash than in the uppermost sample and only a minimal percentage of the feldspar in the uppermost sample. Feldspar inclusions are also significantly smaller $(\sim 0.5 \mathrm{~mm})$ and overall particle sizes are smaller than the uppermost sample. There is a high percentage of amber and green (olivine or pyroxene) colored crystal in the finegrained fraction. The sample is very crystalline due to a high percentage of hornblende. Clasts at 6x magnification appear glassy with lots of very small vesicles but no tunnels.

\subsubsection{Lowermost and oldest sample ( 2 phases)}

The lowest of the Volcán samples contains a pure white matrix with some gray and amber juveniles. Conglomerations of small feldspar chunks with hornblende are common and there is a high percentage of feldspar and hornblende. The sample is very different in color and feldspar/hornblende percentage from the middle sample found stratigraphically above it. Crystals include amber color and very few green (olivine or pyroxene). While not significantly different from one another, this tephra layer was divided into two phases. The primary difference between the phases is the vesicularity, though both have distinctly visible vesicles even at $1 \mathrm{x}$ magnification. Clasts at $6 \mathrm{x}$ magnification show very round holes, some of which are deep, very round, and tunnel-like in the first phase; in the second phase, clasts show some deep pitting but are irregularly shaped. Both samples are from the same stratigraphic layer, but the first phase is from a portion of the tephra with a higher amount of sandy ash.

\subsection{The Boquete lake-sediment core tephra samples}

This sample set represents tephra from a lake-sediment core from an unnamed lake near the town of Boquete, located roughly $10 \mathrm{~km}$ northeast of Barú. The core contained three layers of tephra, with the uppermost of these divided into two distinct phases.

\subsubsection{Uppermost and most recent sample (first phase)}


This sample has a light yellow-white matrix with pure white and gray juvenile clasts ( 2 $\mathrm{mm}$ ) and hornblende inclusions. Some sandy, ashy material is present at the $12 \mathrm{~cm}$ core depth and lots of loose white feldspar $(\sim 1 \mathrm{~mm})$ and similarly sized pieces of hornblende are present. Green olivine (or pyroxene) and amber crystals (likely stained plagioclase) are present. Clasts at 6x magnification show moderately shallow round and irregular holes with some tunnels.

\subsubsection{Uppermost and most recent sample (second phase)}

The second phase of this sample comes from the $14 \mathrm{~cm}$ core depth of the same tephra layer as the first phase. The sample has a glassy white matrix with yellow-white, pure white, and orange-brown juvenile fragments $(2-5 \mathrm{~mm})$ welded with white feldspar chunks $(\sim 0.75 \mathrm{~mm})$ and hornblende $(\sim 0.5 \mathrm{~mm})$. Like the uppermost phase, described in section 4.2.1, hornblende is present in big, crude chunks but angular shards like those found in pre-Columbian ceramic temper in the Barú area are also present. Once washed, vesicular juvenile fragments are visible. A dacitic composition is indicated by the light color. The sample contains sanidine (potassium feldspar) and biotite (sheet-like black crystal) and could be a primary fall-out as it is not overly rounded or reworked. The sample contains lots of microlites in fine-grained portion and does have pumice, which floated to the top in sonication. The sample contains amber-colored crystals $(1 \mathrm{~mm})$, green inclusions $(1 \mathrm{~mm})$, and biotite. Clasts at 6x magnification show shallow, irregular holes.

\subsubsection{Middle sample}

The middle tephra layer sample displays a pure white and light orange-gray juvenile matrix with small, fine ash and yellow pumice. The sample contains loose white feldspar $(\sim 1$ $\mathrm{mm})$ and hornblende $(\sim 0.5 \mathrm{~mm})$ as well as angular sherds of hornblende $(\sim 1 \mathrm{~mm})$. Glassy, darker juveniles are more vesicular and angular than white juveniles. The sample contains a seed, carbon, and green crystal (olivine or pyroxene?). Clasts at 6x magnification show shallow, rounded holes and deeper tunnels. Stretched vesicles possibly indicate that they started forming while still in magma chamber.

\subsubsection{Lowermost (and presumably) oldest sample}


The lowest tephra layer sample is a mixture of ash and orange, white, and gray juveniles. The sample is glassy with some biotite inclusions. Macroscopically, the sample appeared the same as the middle tephra layer, described in 4.2.3, but with smaller chunks. Under the microscope, however, the samples appear very distinct. The lower sample contains a large amount of white feldspar $(\sim 1 \mathrm{~mm})$ and hornblende $(0.25-1 \mathrm{~mm})$ and juvenile fragments $(\sim 2 \mathrm{~mm})$ are very white. The sample contains amber-colored and green (olivine or pyroxene) crystal and rose-colored mineral. The lower sample from the Boquete set is very close in appearance to the uppermost sample from the Boquete lake-sediment core set, described in section 4.1.1 of this paper. Clasts at 6x magnification show shallow round holes, no tunnels.

\subsection{The Barriles archaeological site tephra samples}

This sample set is from the stratigraphy of the Barriles archaeological site, located roughly $16 \mathrm{~km}$ west of the Barú crater. The stratigraphic wall contained two visible tephra layers.

\subsubsection{Uppermost sample}

The uppermost sample from this set contains white, orange, and gray juvenile clasts with hornblende inclusions. Some light yellow-white juveniles (1-4 $\mathrm{mm})$ and hornblende $(\sim 1 \mathrm{~mm})$ are present. There are copious clear, white feldspar $(\sim 0.5-1 \mathrm{~mm})$ inclusions. The sample is glassy and contains some rose-colored and green (olivine or pyroxene) crystal and biotite. Some additional black material may be intermediate to mafic in composition. Clasts at $6 x$ magnification show irregular holes and pitting with no tunnels. Sample fragments are rounded with few vesicles hence appears to either be re-worked by a stream or wind or to be perhaps from a phreatomagmatic eruption. The sample has a considerable amount of silicic material that could be blown in by the wind.

\subsubsection{Lowermost sample}

The lower sample juvenile matrix from Barriles is grayish-white with bright orange. Juvenile fragments are lighter in color than the uppermost sample from this set, described in 4.3.1. The sample is glassy and contains many small hornblende inclusions. The sample is also very 'dirty' and it took considerably longer than the other samples to remove soil in the sonic bath. The sample displays a smaller overall particle size than the uppermost layer $(0.25-0.75$ 
$\mathrm{mm}$ ), though there is one $5 \mathrm{~mm}$ particle. Some amber-colored and green (olivine or pyroxene) crystal inclusions are included. Clasts at $6 x$ magnification show deep, irregular pits and tunnels.

\section{Discussion}

\subsection{Correlating the samples}

Geochemical testing is beyond the budget capacity of most or all local archaeological projects in the Barú area. Tephra analyses in this study, therefore, focused on mineral composition and stratigraphic location to identify isochrons for archaeological teams working in the Barú region that could be utilized reliably and inexpensively by multiple researchers. A mineral assemblage that was compositionally distinctive or unusual enough to be identified as a 'marker' for an individual eruption (per Lowe, 2011: 122), however, was not detected by microscopy.

The samples from the Boquete lake-sediment core (section 4.2 of this paper) from the east of the crater were compositionally different from the Volcán lake-sediment core samples (section 4.1 of this paper) and the Barriles archaeological site samples (section 4.3 of this paper) from the west of the crater to a larger degree than was anticipated. It is probable that tephras were differentially distributed on the east and west side of the crater due to wind currents at the time of each tephra plume. It is also possible and likely for the tephra from a single eruption to vary in composition (e.g., Cioni et al., 2008). If the composition of Boquete area tephra varies too widely within the same eruption, however, it weakens or complicates the validity of the underlying assumption that mineralogical differences could provide a useful chronometric marker for Barú area archaeological sites. An additional complication could arise from the fact that both chemical and morphological composition can change when tephra is reworked (Dugmore and Newton, 2012: 47; Kutterolf et al., 2007: 408). This could explain the lack of resemblance in the earliest and stratigraphically lowest Barriles tephra layer (section 4.3.2 of this paper) to either of the earliest and stratigraphically lowest layers examined in the lakesediment cores. From the list of possible pitfalls in correlation listed by Lowe (2011: 109), the lack of correlation in Barú tephras likely stem from incompleteness of the stratigraphic record, paucity of characterization data, and the possibility of multiple fingerprints from single Barú eruptions. 
Due to the equivocal results of the collected petrographic data, a closer examination of the glass composition of the tephra is imperative as part of a multi-stage methodology. Compositional differences between eruptions can often be seen more distinctively in glasses than minerals as the glass compositions are not limited by crystalline structures or stochiometry (e.g.; Kuehn et al., 2011). Though not unproblematic, as glass composition approximates the composition of magma at the time of eruption it can provide a unique signature or 'fingerprint' of tephra (Lowe, 2011: 120; Tryon et al., 2008). Electron probe microanalysis (EPMS) of individual glass sherds may prove more effective than analysis of bulk samples because the variable phenocrysts, xenocrysts, xenoliths, and detrital grains not related to the eruption are removed (Lowe, 2011: 120; Shane, 2000). Another method of interest is LA-ICPMS (laser ablation inductively-coupled plasma mass spectrometry) to fingerprint trace elements in glass sherds in order to differentiate tephras of potentially similar minerology (Lowe, 2011: 128).

Two main priorities of my original analyses of Barú tephra in archaeological stratigraphy were that the methods be cost-efficient and reproducible for archaeological projects. Innovative applications of new technologies offer both of these benefits and are possible sources of inspiration for future analyses of materials from highland Panamá. The first of these is a specially designed Scanning Electron Microscope (SEM) paired with an energy dispersive spectrometer (EDS) and particle recognition and statistical software by Aspex. While originally designed for industrial use, Watson et al. (2011) utilized the Personal SEM (PSEM) to investigate Laacher See and Hekla proximal samples to look at both glass and non-glass. The PSEM provides a total particle count broken down by material and is able to identify and geochemically characterize tephra shards. It allows for rapid processing of highly accurate data for all of the particles in a sample and records an image and coordinate for each particle. D’Anjou et al. (2014) provide a second novel means to examine tephra via a continuouslyimaging Flow Cytometer and Microscope (FLowCAM®). Previously utilized for biological applications, the FlowCAM® photographs particles in suspension and performs semi-automated analysis of particle images. D'Anjou et al. (2014) experimentally created a reference library of distal-sized fine tephra particles from Grímsvötn and Askja volcanoes in Iceland and lake sediment samples from Norway against which other particle morphologies could be automatically compared. The method is not as labor intensive as traditional microscopy and is nondestructive of samples. 
The methods described by Watson et al. (2011) and D'Anjou et al. (2014) are capable of providing nonsubjective particle counts and descriptions and create visual archives of cryptotephra compositions. The ability of the methods to analyze visible medial tephra layers and possibly detect 'missing' tephra layers in the Barú region stratigraphy is desirable. The methods also allow multiple researchers to contribute to an image library of tephras that are stratigraphically or contextually linked to archaeological materials to expand current understanding of how volcanic materials and the pre-Columbian artifact record intersect in highland western Panamá.

\subsection{Tephra as 'problematic' artifact rather than ecofact?}

Tephra is not generally considered the product of human manipulation. It is instead an ecofact, 'a relic of other-than-human engagements with matter, climate, weather, and biology' (Jones, 2005: 85). A subset of small, crude lithic objects recovered during my fieldwork as well as from the Adaptive Radiations project and recorded by Linares and Ranere (1980), however, complicate an easy categorization between artifact and ecofact. The Adaptive Radiations publication included these objects in a chapter titled 'Miscellaneous artifacts of special use' (Linares, 1980). What that use could be is entirely opaque. Three of the pumice objects are described simply as 'problematic' while one of the pieces is grooved at the top, 'potentially for use as a pendant'; no clear idea of the form or function of the small $(2.4-4.5 \mathrm{~cm})$ objects is possible (Linares, 1980: 140). Each of the objects was recovered from a domestic context from under a house floor. My own fieldwork recovered four similar tephra objects from a burial site (BE-16-KH [KOT]). The pieces are worked and are very distinctively 'something'. Two of the tephra pieces have holes that are drilled only part of the way through the object (Figure 14: a, b), which negates their possible use as beads. Two of the pieces seem somewhat complete (Figure 14: b, d), though the other two (Figure 14: a, c) are missing a portion of the original form. One possible theory is that they are remnants of crude sculptures made from tephra.

If the worked pieces of tephra are sculptural remnants, they represent something of a midway point between the ethnographically documented use of organic materials and more permanent sculptures or objects made of stone or metal from the region. The friability of the tephra objects makes them fairly impermanent, though their ease of manufacture could have made them desirable if their form rather than material or longevity were most significant in the 
context for which they were created. The frustration, archaeologically, is the nagging sense that 'Human memory is encoded in air currents and river sediments. Eskers of ash wait to be scooped up, lives reconstituted' (Michaels, 1996: 53), but there is currently an inability to interpret the encoding. Perhaps the worked tephra objects were directly linked in the minds of Barú area residents to volcanic eruption through memory or ethnographic stories. In such an interpretation, the tephra objects would join a volcanic bomb found curated in a manufacturing site as well as basalt columns and dacite slabs transported through the study area and incorporated into burial contexts in the Barú region (Holmberg, 2007: 291-2; 2009, 2010) as volcanic materials with distinctly cultural associations.

\subsection{Conclusions}

The lack of uniform distribution, preservation, and secure dating of Barú tephras in highland western Panamá prevents the creation of a macroscopic 'barcode' such as is possible with Icelandic tephra layers over short-range distances (e.g.; Dugmore and Newton, 2012: 46-7). A great deal of further investigation of the tephra record is requisite to understand the relationship between volcanic eruptions and pre-Columbian populations in the Barú region. This paper provides a description of preliminary analysis of Barú tephra and is intended as a contribution to the data currently published on medial tephra from archaeological contexts in the region. In doing so, this work builds on seminal research by Linares and Ranere (1980) that merits expansion by additional research vantages and techniques. In particular, innovative uses of new technologies such as PSEM (Watson et al., 2011) or FlowCAM® (D'Anjou et al., 2014), which are capable of creating a visual archive of tephras that archaeologists can build and refine in tandem with photographic archives and typologies of artifacts, are suggested as promising.

Anthropologist Michel-Rolph Trouillot (1997) influentially wrote about the 'silences' in historical narrative, referring to the gaps inherent in both the creation and interpretation of the historical archives that produce the final product of history. Similarly, stratigraphy can be seen as an archive of prehistoric past natural events that is filled with sometimes frustrating silences. In an inadvertently poetic phrase in a discussion of tephra geochemistry, Kristjándóttir et al. (2007: 156) state that the term cryptotephra is meant to convey 'the concealed nature of the tephra'. To turn this phrase slightly, there can also be a 'concealed culture' of tephra when it is examined as an ecofact that provides one of the few records of human experience with volcanic eruptions in 
the Barú area. As proposed in the case of crude, worked fragments made of tephra, the material can at times be transformed from ecofact to artifact.

The Barú area is similar to much of Central America in that relatively little tephrochronology data are collected to date, making correlation and interpretation of tephra difficult. This does not mean, however, that the endeavor is not worth attempting. Engagement with incomplete or imperfect tephra sequences is rightly stated to be an important part of a 'total tephrochronology' (Dugmore and Newton, 2012). Engagement with the imperfection entailed in meshing multidisciplinary data sets and different scientific communities with interests in tephra, particularly in lesser studied regions, could by extension be considered part of a 'total' view of tephra that this paper encourages.

\section{Acknowledgements}

The fieldwork and analyses represented in this paper were funded by the Wenner-Gren Foundation and a Fulbright IIE grant. The Smithsonian Tropical Research Institute (STRI) in Panamá served as host institution during fieldwork. Enrique Moreno (STRI) was invaluable in helping me open the lake-sediment cores; Richard Cooke (STRI) was the same for the overall project. The lake-sediment core I used to obtain the sample set from Volcán was collected by Hermann Behling (Georg-August University; Göttingen, Germany) and his permission to open the core is greatly appreciated. Kristi Wallace (USGS) generously and patiently shared tephra insights and methodology prior to fieldwork. Michael Ort and Nancy Riggs (Northern Arizona University) steered the tephra analyses and hosted me in Flagstaff, where the USGS allowed use of their lab, an Olympus DP11 microscope camera attachment, and a fiber optic light. The work of Robin Torrence (Australian Museum) in Papua New Guinea is to thank for the tephra envy I feel for the clearer stratigraphy of her well-done Willaumez Peninsula research. The work of Payson Sheets, a member of the Adaptive Radiations (Linares and Ranere 1980) project at Barú, is to thank for a great deal of the thought given to archaeology in volcanic regions of Central America and elsewhere. This paper benefited greatly from astute, helpful suggestions of two anonymous reviewers and editorial guidance of Felix Reide.

\section{References}


Alvarado, G.E., Soto, G.J., Schmincke, H.U., Bolge, L.L., Sumita, M., 2006. The 1968 andesitic lateral blast eruption at Arenal volcano, Costa Rica. Journal of Volcanology and Geothermal Research 157, 9-33.

Anchukaitis, K., Horn, S., 2005. A 2000-year reconstruction of forest disturbance from southern Pacific Costa Rica. Palaeogeography, Palaeoclimatology, Palaeoecology 221 (1-2), 35-54.

Behling, H., 2000. A 2860-year high-resolution pollen and charcoal record from the Cordillera de Talamanca in Panama: a history of human and volcanic forest disturbance. The Holocene 10, 387-393.

Bertrand, S., Castiaux, J., Juvigné, E., 2008. Tephrostratigraphy of the late glacial and Holocene sediments of Puyehue Lake (Southern Volcanic Zone, Chile, 40 ${ }^{\circ}$ S). Quaternary Research 70, 343-357.

Bolge, L.L., Carr, M.J., Feigenson, M.D., Alvarado, G.E., 2006. Geochemical stratigraphy and magmatic evolution at Arenal volcano, Costa Rica. Journal of Volcanology and Geothermal Research 157, 34-48.

Breitkreuz, C., de Silva, S.L., Wilke, H.G., Pfänder, J.A., Renno, A.D., 2014. Neogene to Quaternary ash deposits in the Coastal Cordillera in northern Chile: Distal ashes from supereruptions in the Central Andes. Journal of Volcanology and Geothermal Research 269, 6882.

Cioni, R., D'Oriano, C., Bertagnini, A., 2008. Fingerprinting ash deposits of small scale eruptions by their physical and textural features. Journal of Volcanology and Geothermal Research 177 (1), 277-287.

Clift, P.D., Chan, L.H., Blusztajn, J., Layne, G.D., Kastner, M., Kelly, R.K., 2005. Pulsed subduction accretion and tectonic erosion reconstructed since $2.5 \mathrm{Ma}$ from the tephra record offshore Costa Rica. Geochemistry Geophysics Geosystems 6. 
Cole, P.D., Fernandez, E., Duarte, E., Duncan, A.M., 2005. Explosive activity and generation mechanisms of pyroclastic flows at Arenal volcano, Costa Rica between 1987 and 2001 Bulletin of Volcanology 67, 695-716

Cooke, R., 2005. Prehistory of native Americans on the Central American land bridge: colonization, dispersal, and divergence. Journal of Archaeological Research 13 (2), 129-187.

Cooke, R., Sánchez Herrera, L.A., Rocío Carvajal, D., Griggs, J., Isaza Aizpurua, I.I., 2003. Los pueblos indígenas de Panamá durante el siglo IVA: Tranformaciones sociales y culturales desde una perspectiva arqueológica y paleoecológica. Mesoamérica 45, 1-34.

D'Anjou, R., Balascio, N., Bradley, R., 2014. Locating crytotephra in lake sediments using fluid imaging technique. Journal of Paleolimnology 52, 257-264.

Daga, R., Ribeiro Guevara, S., Poire, D.G., Arribére, M., 2014. Characterization of tephras dispersed by the recent eruptions of volcanoes Calbuco (1961), Chaitén (2008) and Cordón Caulle Complex (1960 and 2011), in Northern Patagonia. Journal of South American Earth Sciences 49, 1-14.

Dahlin, B., 1980. Surveying the Volcan region with the posthole digger, in: Linares, O., Ranere, A. (Eds.), Adaptive Radiations in Prehistoric Panama. Harvard University Press, Cambridge, pp. 276-279.

Dickau, R., Ranere, A., Cooke, R., 2007. Starch grain evidence for the preceramic dispersal of maize and root crops unto tropical dry and humid forests of Panama. Proceedings of the National Academy of Sciences 104 (9), 3651-3656.

Dugmore, A., Newton, A., 2012. Isochrons and beyond: maximising the use of tephrochronology in geomorphology. Jökull 62, 39-52. 
Dull, R., Southon, J., Sheets, P., 2001. Volcanism, ecology and culture: A reassessment of the Volcan Ilopango TBJ eruption in the southern Maya realm. Latin Amer Antiq 12 (1), 25-44.

Fontijn, K., Lachowycz, S.M., Rawson, H., Pyle, D.M., Mather, T.A., Naranjo, J.A., MorenoRoa, H., 2014. Late Quaternary tephrostratigraphy of southern Chile and Argentina. Quaternary Science Reviews 89, 70-84.

Friedrich, W., Kromer, B., Friedrich, M., Heinemeier, J., Pfeiffer, T., Talamo, S., 2006. Santorini eruption radiocarbon dated to 1627-1600 BC. Science 312 (5773), 548.

Gonzalez, S., Huddart, D., Israde -Alcántara, I., Domínguez-Vázquez, G., Bischoff, J., Felstead, N., Paleoindian sites from the Basin of Mexico: Evidence from stratigraphy, tephrochronology and dating. Quaternary International.

Haberzettl, T., Corbella, H., Fey, M., Janssen, S., Lücke, A., Mayr, C., Ohlendorf, C., Schäbitz, F., Schleser, G., Wille, M., Wulf, S., Zolitschka, B., 2007. Lateglacial and Holocene wet-dry cycles in southern Patagonia: chronology, sedimentology and geochemistry of a lacustrine record from Laguna Potrok Aike, Argentina. The Holocene 17 (3), 297-310.

Hansen, B.C.S., Rodbell, D.T., Seltzer, G.O., León, B., Young, K.R., Abbott, M., 2003. Lateglacial and Holocene vegetational history from two sites in the western Cordillera of southwestern Ecuador. Palaeogeography, Palaeoclimatology, Palaeoecology 194, 79-108.

Holmberg, K., 2007. Beyond the catastrophe: The volcanic landscape of Barú, western Panamá, in: Grattan, J., Torrence, R. (Eds.), Living Under the Shadow: Cultural Impacts of Volcanic Eruptions. Left Coast Press, Walnut Creek, CA, pp. 274-297.

Holmberg, K., 2009. Nature, Culture, and the Volcano: The Archaeological Significance of the Volcán Barú in the Chiriquí province of Panamá, PhD thesis, Department of Anthropology. Columbia University, New York. 
Holmberg, K., 2010. Placing immateriality: Situating the material of highland Chiriquí. Internet Archaeology 28, http://intarch.ac.uk/journal/issue28/holmberg index.cfm.

Horn, S., 2007. Late Quaternary lake and swamp sediments: Climate and environment, in: Bundschuh, J., Alvarado, G. (Eds.), Central America: Geology, Resources and Hazards. Taylor \& Francis, London.

IRHE, 1987. Instituto de Recursos Hidraulicos y Electrificacion. Final report on the reconnaissance study of geothermal resources in the Republic of Panama. Instituto de Recursos Hidraulicos y Electrificacion - InterAmerican Development Bank - Organización Latinoamericana de Energía (IRHE - IDB - OLADE), Panama City, Panama and Quito, Ecuador, p. 72 p.

Johnston, S., Thorkelson, D., 1997. Cocos-Nazca slab window beneath Central America. Earth and Planetary Science Letters 146, 465-474.

Jones, M., 2005. Environmental archaeology, in: Renfrew, C., Bahn, P. (Eds.), Archaeology: The Key Concepts. Routledge, London, pp. 85-89.

Kilian, R., Hohner, M., Biester, H., Wallrage-Adams, H., Stern, C., 2003. Holocene peat and lake sedient tephra record from the southernmost Chilean Andes (53-55 degrees S). Revista Geológica de Chile 30 (1), 23-37.

Kristjánsdóttir, G.B., Stoner, J., Jennings, A., Andrews, J., Grönvold, K., 2007. Geochemistry of Holocene cryptotephras from the North Iceland Shelf (MD99-2269): intercalibration with radiocarbon and palaeomagnetic chronostratigraphies. Holocene 17, 155-176.

Kuehn, S.C., Froese, D.G., Shane, P.A.R., 2011. The INTAV intercomparison of electron-beam microanalysis of glass by tephrochronology laboratories: Results and recommendations. Quaternary International 246, 19-47. 
Kutterolf, S., Schacht, U., Wehrmann, H., Freundt, A., Mörz, T., 2007. Onshore to offshore tephrostratigraphy and marine ash diagenesis, in: Bundschuh, J., Alvarado, G. (Eds.), Central America: Geology, Resources and Hazards. Taylor \& Francis, London, pp. 395-418.

Le Pennec, J., Jaya, D., Samaniego, P., Ramón, P., Moreno Yánez, S., Egred, J., Van der Plicht, J., 2008. The AD 1300-1700 eruptive periods at Tungurahua volcano, Ecuador, revealed by historical narratives, stratigraphy and radiocarbon dating. Journal of Volcanology and Geothermal Research.

Linares, O., 1980. Miscellaneous artifacts of special use, in: Linares, O., Ranere, A. (Eds.), Adaptive Radiations in Prehistoric Panama. Harvard University Press, Cambridge, pp. 139-145.

Linares, O., Ranere, A., 1980. Adaptive Radiations in Prehistoric Panama, Peabody Museum Monographs. Harvard University, Cambridge, MA.

Linares, O., Sheets, P., Rosenthal, J., 1975. Prehistoric Agriculture in Tropical Highlands. Science 187, 137-145.

Lowe, D.J., 2011. Tephrochronology and its application: A review. Quaternary Geochronology 6, 107-153.

Luhr, J.F., Navarro-Ochoa, C., Savov, I.P., 2010. Tephrochronology, petrology and geochemistry of Late-Holocene pyroclastic deposits from Volcán de Colima, Mexico. Journal of Volcanology and Geothermal Research 197, 1-32.

Manning, S., 1999. A Test of Time: The Volcano of Thera and the Chronology and History of the Aegean and East Mediterranean in the Mid Second Millennium BC. Oxbow Books, Oxford.

Manning, S., Bronk Ramsey, C., Kutschera, W., Higham, T., Kromer, B., Steier, P., Wild, E., 2006. Chronology for the Aegean Late Bronze Age 1700-1400 BC. Science, April 28 312, $565-$ 569. 
Mehringer, P.J., Sarna-Wojcicki, A.M., Wollwage, L.K., Sheets, P., 2005. Age and extent of the Ilopango TBJ tephra inferred from a holocene chronostratigraphic reference Section, lago de yojoa, Honduras Quaternary Research 63, 199-205

Michaels, A., 1996. Fugitive Pieces. Random House, New York.

Morell, K., Fisher, D., Gardner, T., 2008. Inner forearc response to subduction of the Panama Fracture Zone, southern Central America. Earth and Planetary Science Letters 265, 82-95.

Newton, A., Dugmore, A., Gittings, B., 2007. Tephrabase: tephrochronology and the development of a centralized European database. Journal of Quaternary Science 22.

Newton, A., Metcalfe, S., Davies, S., Cook, G., Barker, P., Telford, R., 2005a. Late Quaternary volcanic record from lakes of Michoacan, central, Mexico. Quaternary Science Reviews 24, 91104.

Newton, A.J., Metcalfe, S.E., 1999. Tephrochronology of the Toluca Basin, central Mexico. Quaternary Science Reviews 18, 1039-1059.

Newton, A.J., Metcalfe, S.E., Davies, S.J., Cook, G., Barker, P., Telford, R.J., 2005b. Late Quaternary volcanic record from lakes of Michoacán, central Mexico. Quaternary Science Reviews 24, 91-104.

Nicoll, K., Murphy, L.R., 2014. Soil and sediment archives of ancient landscapes, paleoenvironments, and archaeological site formation processes. Quaternary International 342, 14.

Pearson, C., Manning, S., Coleman, M., Jarvis, K., 2005. Can tree-ring chemistry reveal absolute dates for past volcanic eruptions? J Archaeol Sci 32, 1265-1274. 
Piperno, D., 2006. Quaternary environmental history and agricultural impact on vegetation in Central America. Annals of the Missouri Botanical Garden 93 (2), 274-296.

Piperno, D., Andres, T., Stothert, K., 2000a. Phytoliths in Cucurbita and other Neotropical Cucurbitaceae and their occurrence in early archaeological sites from the lowland American tropics. J Archaeol Sci 27, 193-208.

Piperno, D., Ranere, A., Holst, I., Hansell, P., 2000b. Starch grains reveal early root crop horticulture in the Panamanian tropical forest. Nature 407, 894-897.

Rabek, K., Ledbetter, M.T., Williams, D.F., 1985. Tephrochronology of the western Gulf of Mexico for the last 185,000 years. Quaternary Research 23, 403-416.

Rodbell, D.T., Bagnato, S., Nebolini, J.C., Seltzer, G.O., Abbott, M.B., 2002. A Late GlacialHolocene Tephrochronology for Glacial Lakes in Southern Ecuador. Quaternary Research 57, 343-354.

Rosenthal, J., 1980. Excavations at Barriles (BU-24): A small testing program, in: Linares, O., Ranere, A. (Eds.), Adaptive Radiations in Prehistoric Panama. Harvard University Press, Cambridge, pp. 288-291.

Schiff, C.J., Kaufman, D., Wallace, K., Werner, A., Ku, T.L., Brown, T.A., 2008. Modeled tephra ages from lake sediments, base of Redoubt Volcano, Alaska. Quaternary Geochronology $3(1-2)$.

Shane, P., 2000. Tephrochronology: A New Zealand case study. Earth Science Reviews 49 (1-4), 223-259.

Shaw, A.M., Hilton, D.R., Fischer, T.P., Walker, J.A., de Leeuw, G.A.M., 2006. Helium isotope variations in mineral separates from Costa Rica and Nicaragua: Assessing crustal contributions, timescale variations and diffusion-related mechanisms Chemical Geology 230, 124-139 
Sheets, P., 1979. Maya recovery from volcanic disasters: Ilopongo and Ceren. Archaeology 32, $32-42$.

Sherrod, D., Vallance, J., Tapia Espinosa, A., McGeehin, J., 2007. Volcán Barú: Eruptive history and volcano-hazards assessment (Open-File Report 2007-1401). United States Geological Survey, Reston, VA.

Siebert, L., Alvarado, G., Vallance, J., de Vries, B.v.W., 2006. Large-volume volcanic edifice failures in Central America and associated hazards. Geological Society of America Special Paper 412.

Siebert, L., Kimberly, P., Pullinger, C.R., 2004. The voluminous Acajutla debris avalanche from Santa Ana volcano, western El Salvador, and comparison with other Central American edificefailure events, in: I., R.W., J., B.J., L., L.D., J., C.M., J., M.J. (Eds.), Natural Hazards in El Salvador. Geological Society of America Special Papers, pp. 5-23.

Soto, G., Alvarado, G., 2006. Eruptive history of Arenal volcano, Costa Rica, 7 ka to present. Journal of Volcanology and Geothermal Research 157, 254-269.

Tonneijck, F.H., Hageman, J.A., Sevink, J., Verstraten, J.M., 2008. Tephra stratification of volcanic ash soils in Northern Ecuador. Geoderma 144, 231-247.

Trouillot, M.-R., 1997. Silencing the Past: Power and the Production of History. Beacon Press, Boston.

Tryon, C.A., Roach, N.T., Logan, M.A.L., 2008. The Middle Stone Age of the northern Kenyan Rift: age and context of new archaeological sites from the Kapedo Tuffs. J Hum Evol $55,652-664$. 
Van Wyk de Vries, B., Grosse, P., Alvarado, G., 2007. Volcanism and volcanic landforms, in: Bundschuh, J., Alvarado, G. (Eds.), Central America: Geology, Resources and Hazards. Taylor \& Francis, London, pp. 123-154.

Watson, J., Tryon, C.A., Vicéns, M.C., 2011. Faster and more accurate processing of samples for microtephrochronology, in: Turbanti-Memmi, I. (Ed.), Proceedings of the 37th International Symposium on Archaeometry, 13th-16th May 2008, Sienna, Italy. Springer/Verlag, pp. 509-513.

Watt, S.F.L., Pyle, D.M., Naranjo, J.A., Rosqvist, G., Mella, M., Mather, T.A., Moreno, H., 2011. Holocene tephrochronology of the Hualaihue region (Andean southern volcanic zone, $\left.\sim 42^{\circ} \mathrm{S}\right)$, southern Chile. Quaternary International 246, 324-343.

Zeilinga de Boer, J., Defant, M.J., Stewart, R.H., Restrepo, J.F., Clark, L.F., Ramirez, A.H., 1988. Quaternary calc-alkaline volcanism in western Panama: regional variation and implication for the plate tectonic framework. Journal of South American Earth Sciences 1, 275-293.

Zolitschka, B., Schäbitz, F., Lücke, A., Corbella, H., Ercolano, B., Fey, M., Haberzettl, T., Janssen, S., Maidana, N., Mayr, C., Ohlendorf, C., Oliva, G., Paez, M.M., Schleser, G.H., Soto, J., Tiberi, P., Wille, M., 2006. Crater lakes of the Pali Aike Volcanic Field as key sites for paleoclimatic and paleoecological reconstructions in southern Patagonia, Argentina. Journal of South American Earth Sciences 21, 294-309.

\section{Figure list}

Figure 1: Archaeological sites in relation to heuristic tephra fall radii

Figure 2: Representative tephra layer variability in surveyed archaeological site stratigraphy

Figure 3: Source locations of the three tephra sample locations. Isothickness lines indicate USGS estimates of major tephra falls from the most recent eruption of Barú (Sherrod et al. 2007: Figure 4).

Figure 4 - tephra stratigraphy from the two lake-sediment cores and the archaeological stratigraphy with associated radiocarbon dates

Figure 5: Volcán uppermost tephra sample 
Figure 6: Volcán middle tephra sample

Figure 7: Volcán lowermost tephra sample (2 phases labeled as 'a' and 'b')

Figure 8: Boquete uppermost tephra sample, first phase

Figure 9: Boquete uppermost tephra sample, second phase

Figure 10: Boquete middle tephra sample

Figure 11: Boquete lowermost tephra sample

Figure 12: Barriles uppermost tephra sample

Figure 13: Barriles lower tephra sample

Figure 14: Tephra stratigraphy from the two lake-sediment cores and the archaeological stratigraphy with associated radiocarbon dates

Figure 15: Worked tephra pieces 


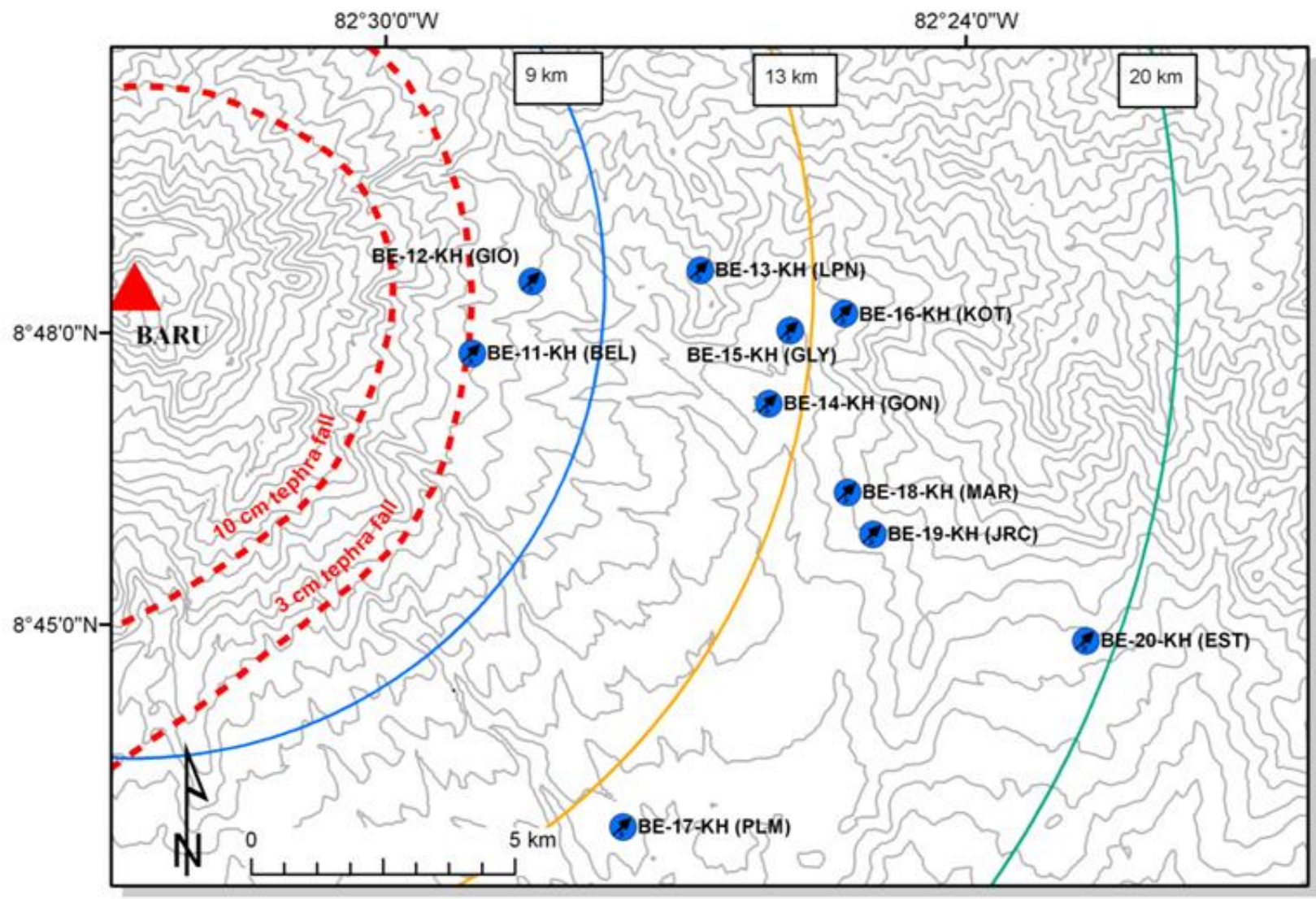

$9 \mathrm{~km}$ buffer from Baru summit =- - USGS estimation of $10 \mathrm{~cm}$ and $3 \mathrm{~cm}$ tephra falls

$13 \mathrm{~km}$ buffer from Baru summit — $200 \mathrm{~m}$ contour (from srtm)

$20 \mathrm{~km}$ buffer from Baru summit survey sites 


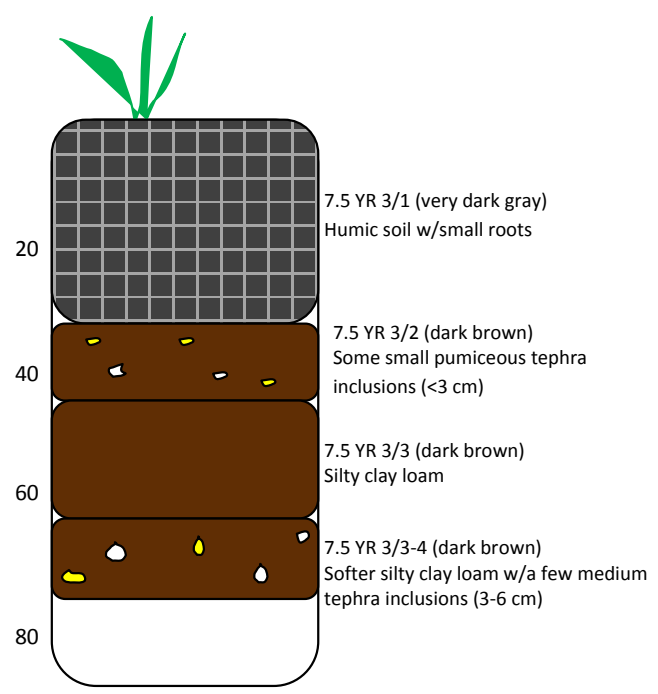

BE-11-KH (BEL)

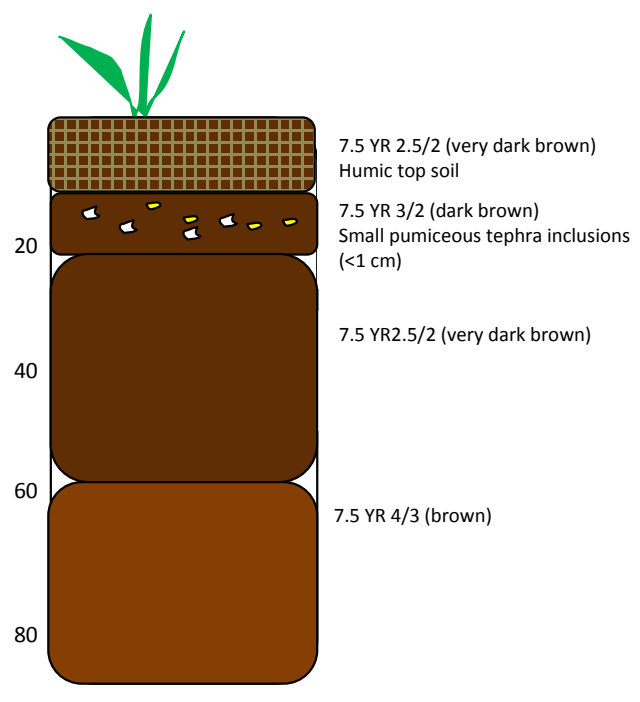

BE-16-KH (КОT)
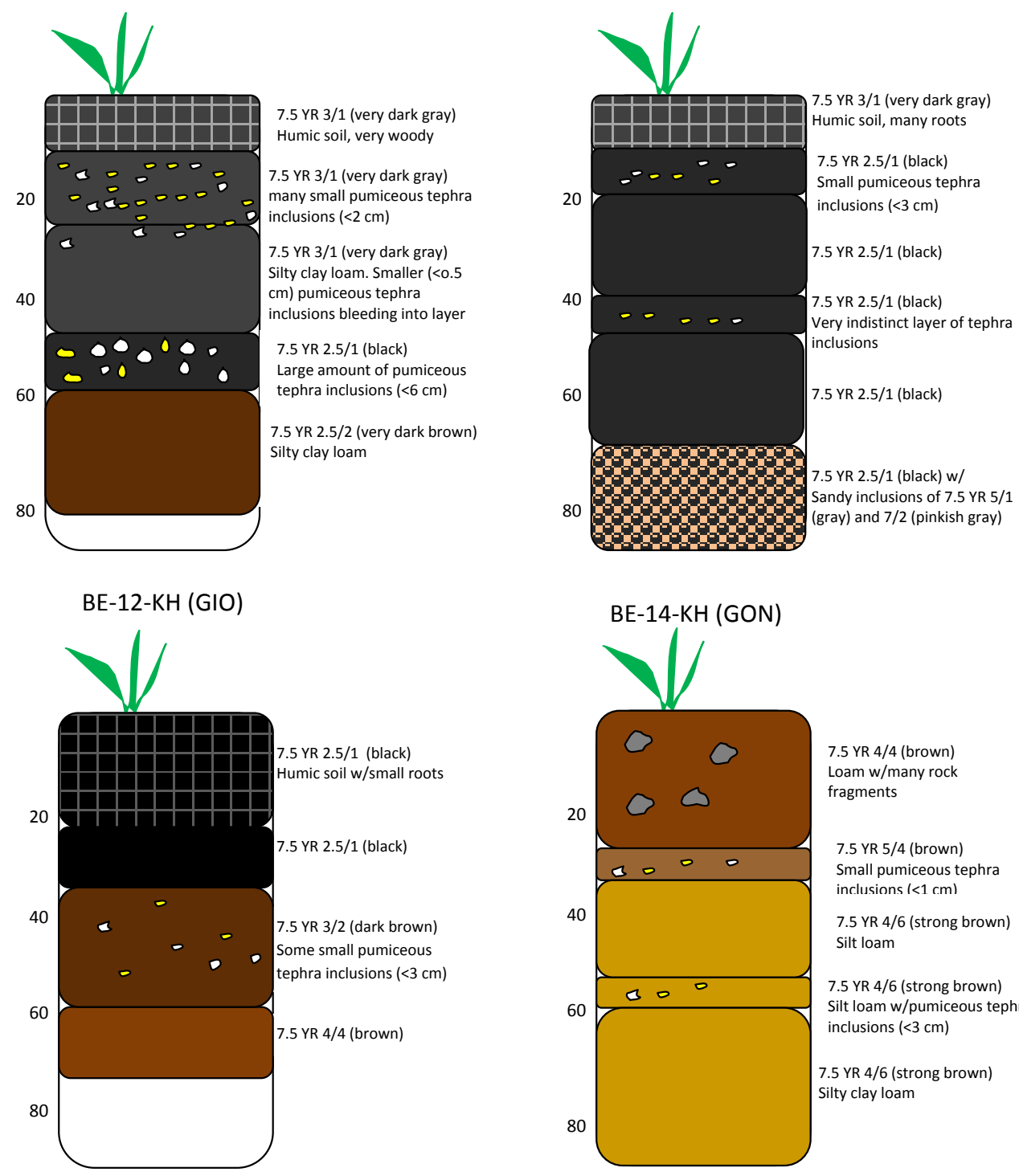

BE-18-KH (MAR)

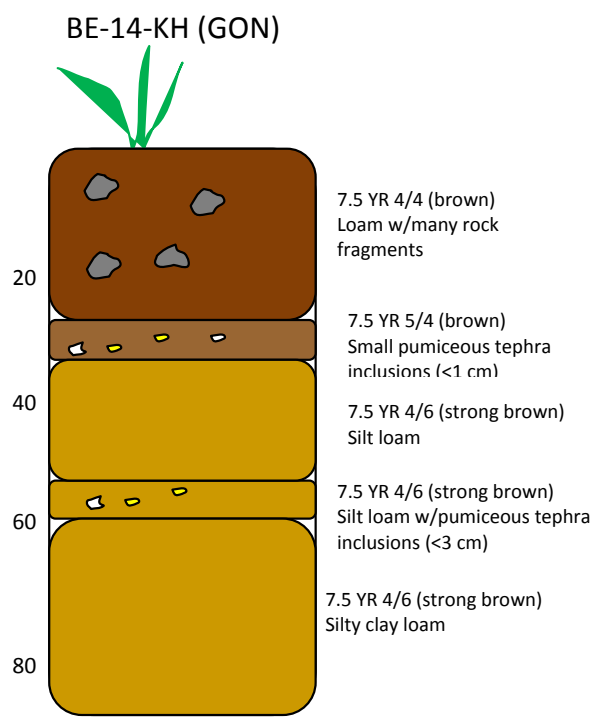

BE-20-KH (EST) 


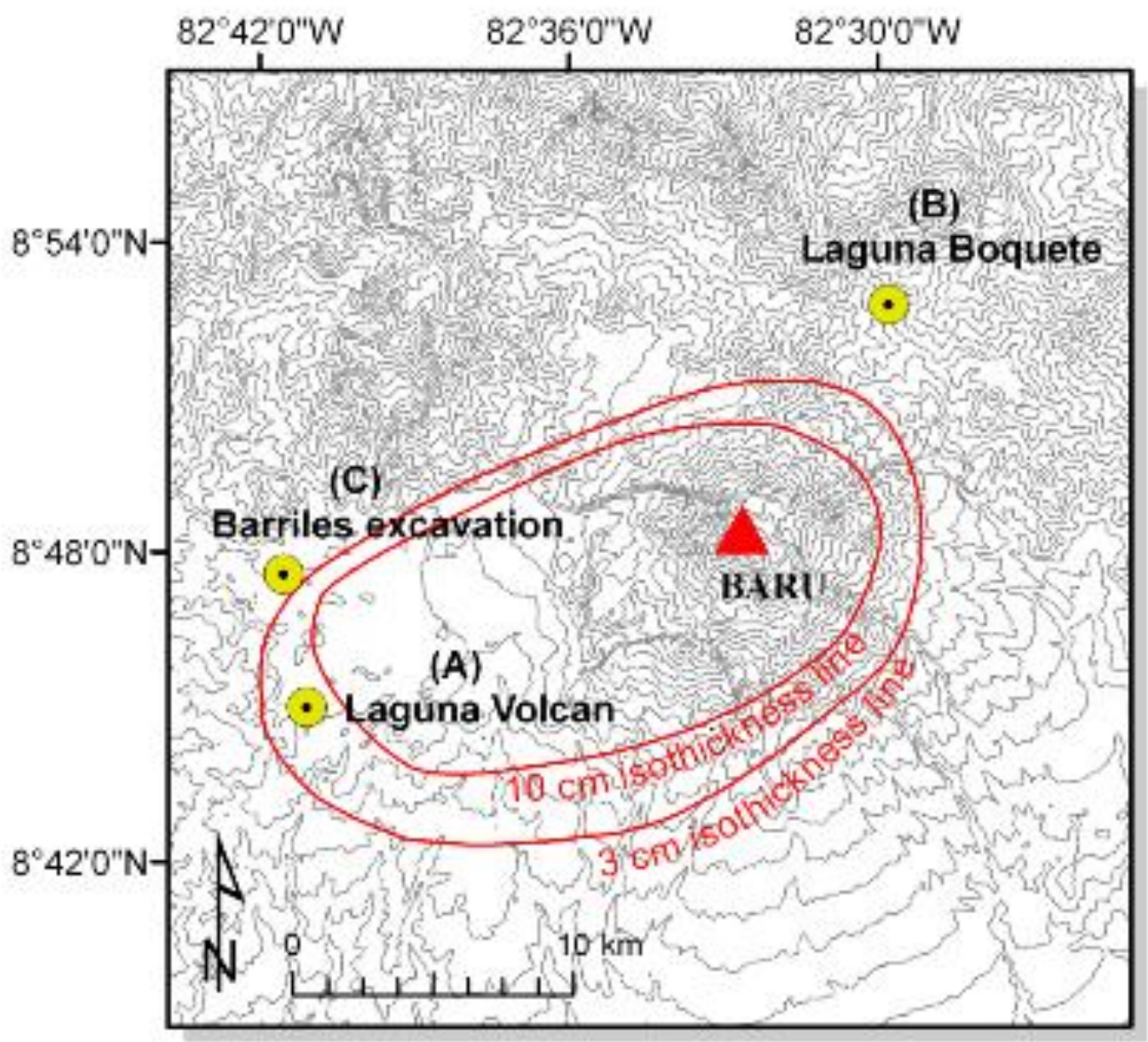




\section{Volcán}

lake-sediment core

$\mathrm{cm}$

10

20

30

40

50

60

70

80

90

100

110

120

\section{Boquete}

lake-sediment core

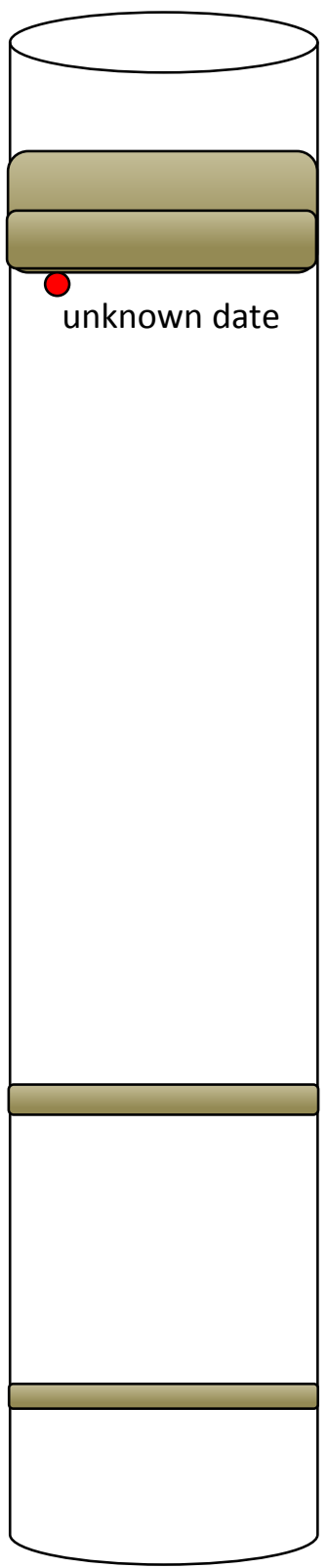

Barriles

archaeological stratigraphy

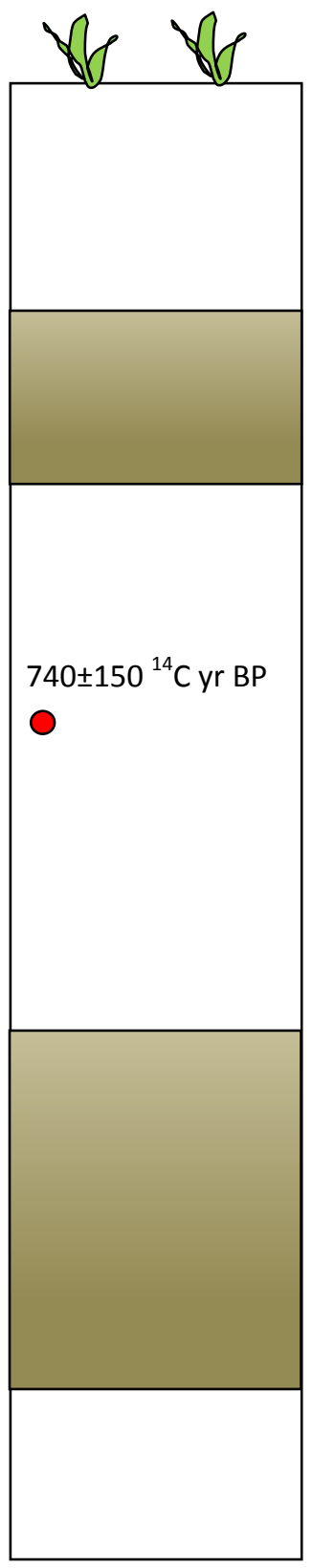

$\mathrm{cm}$

10

20

30

40

50

60

70

80

90

100

110

120

- radiocarbon sample location and associated date 

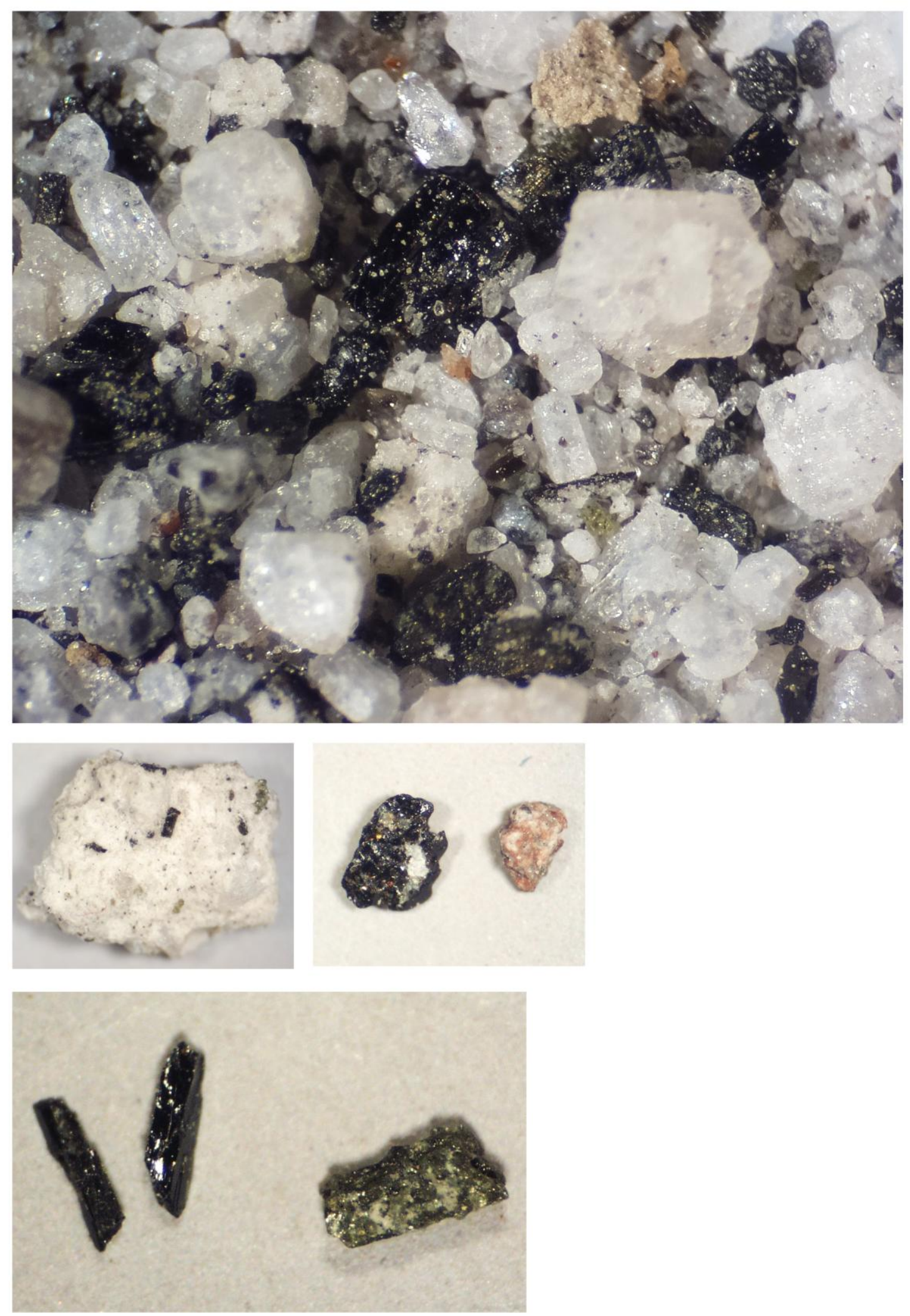

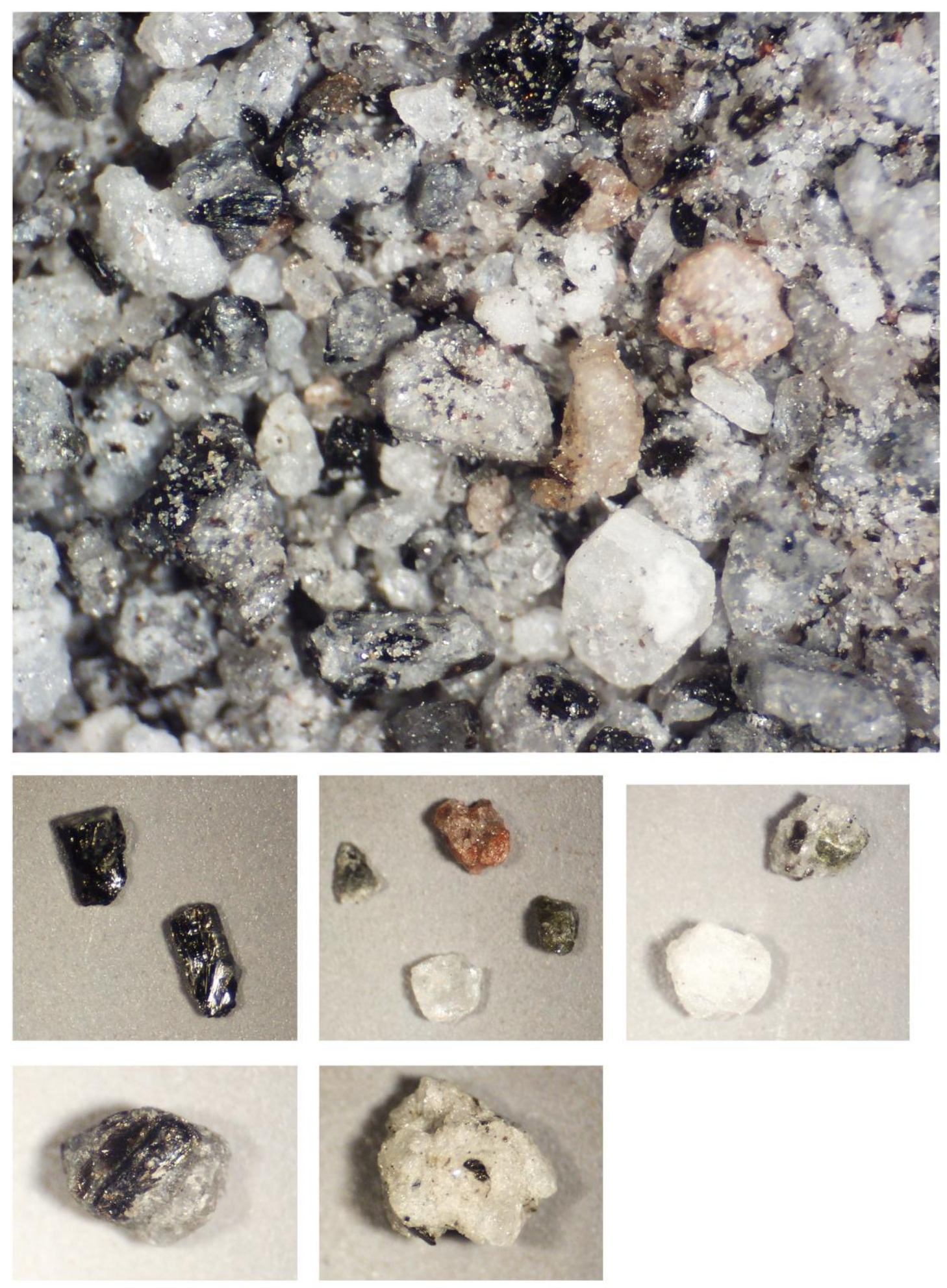

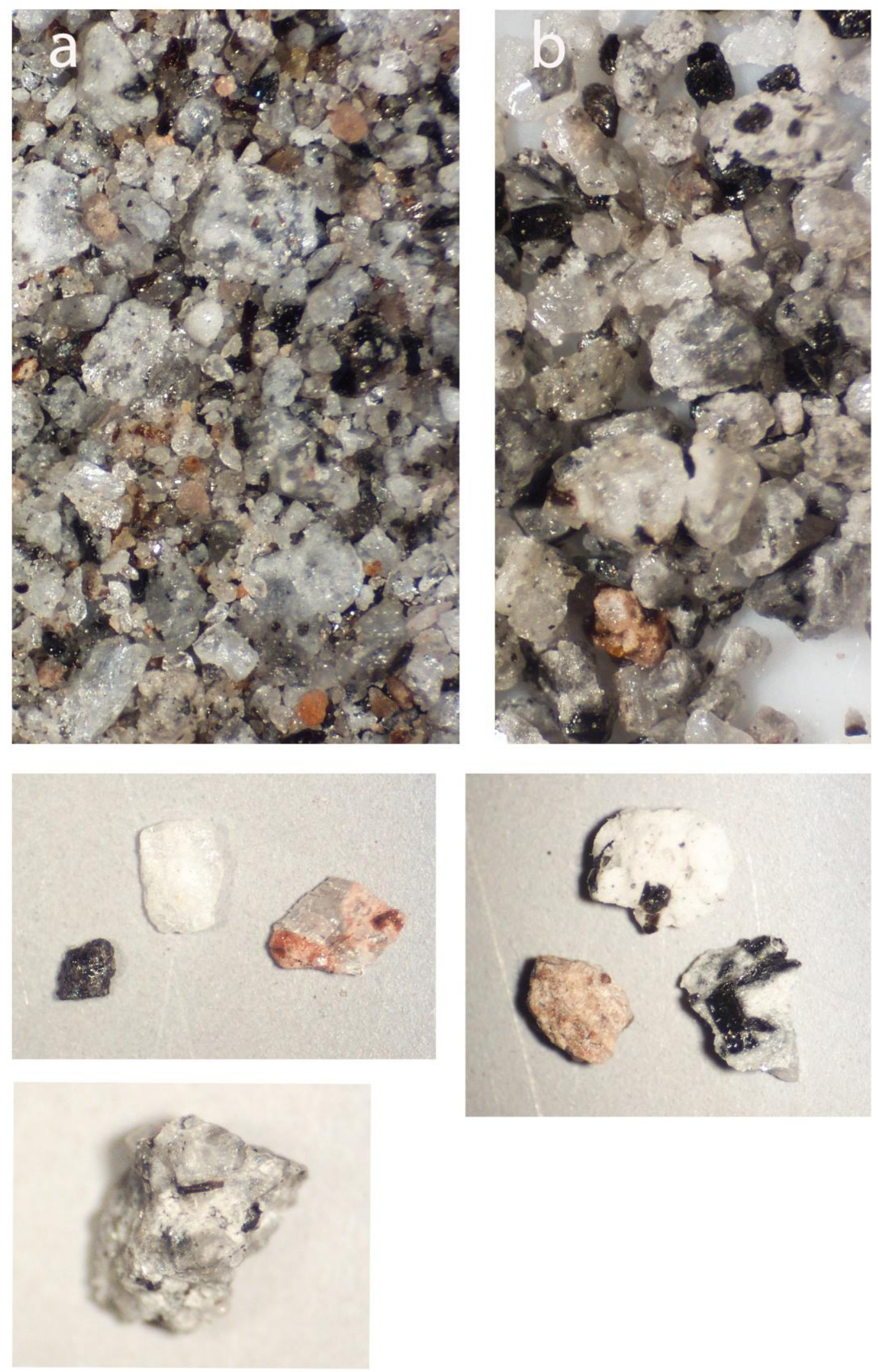

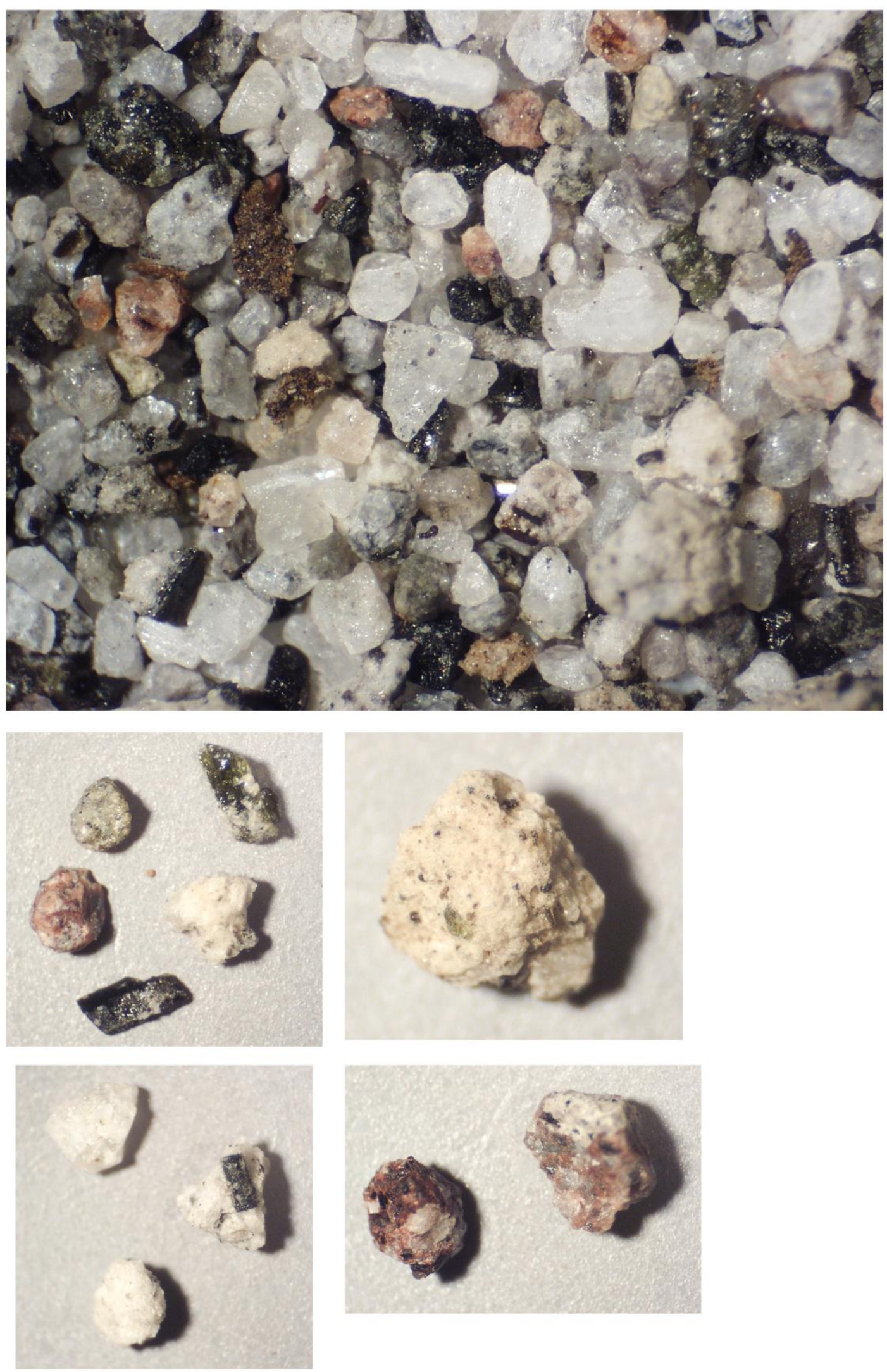

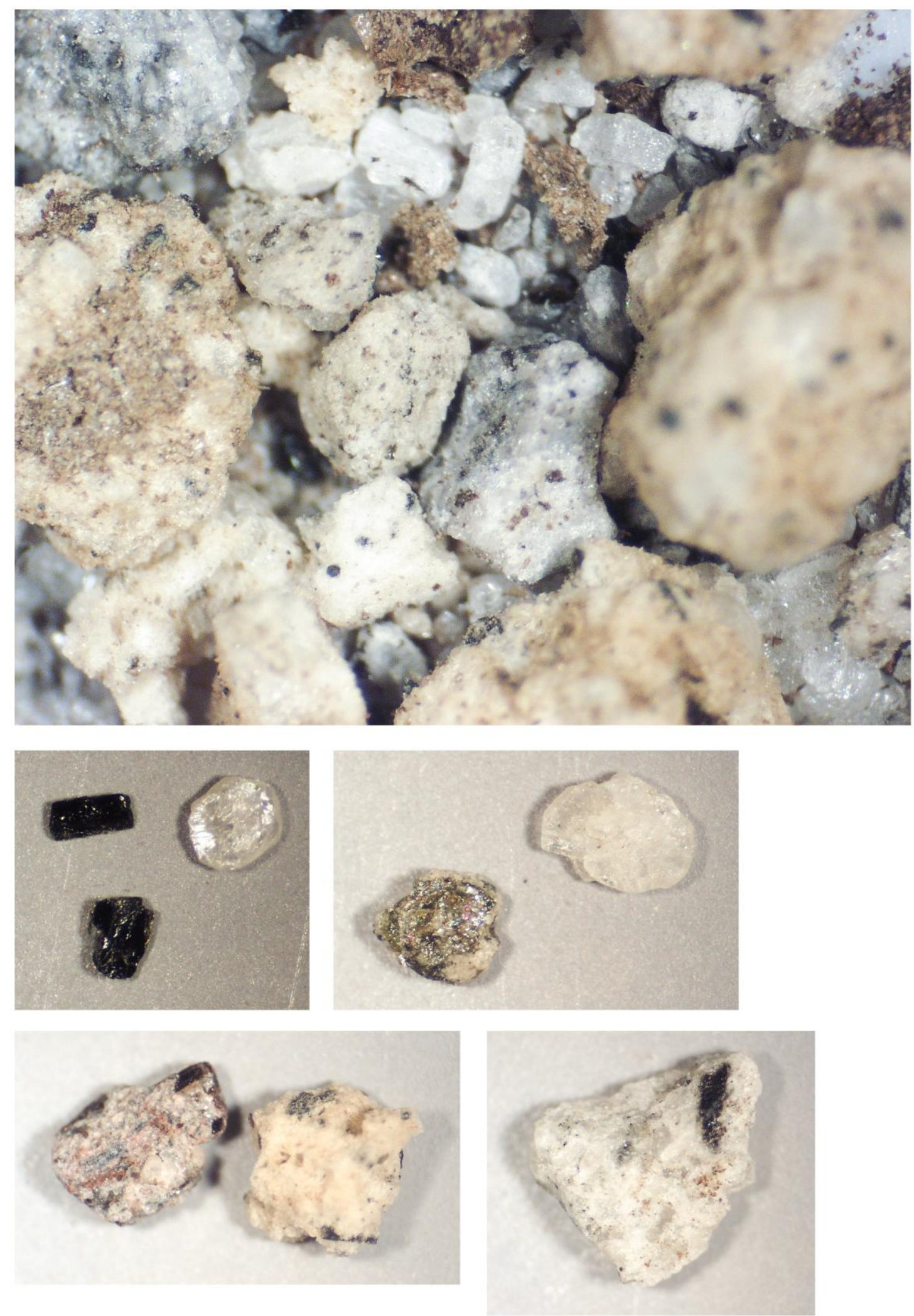

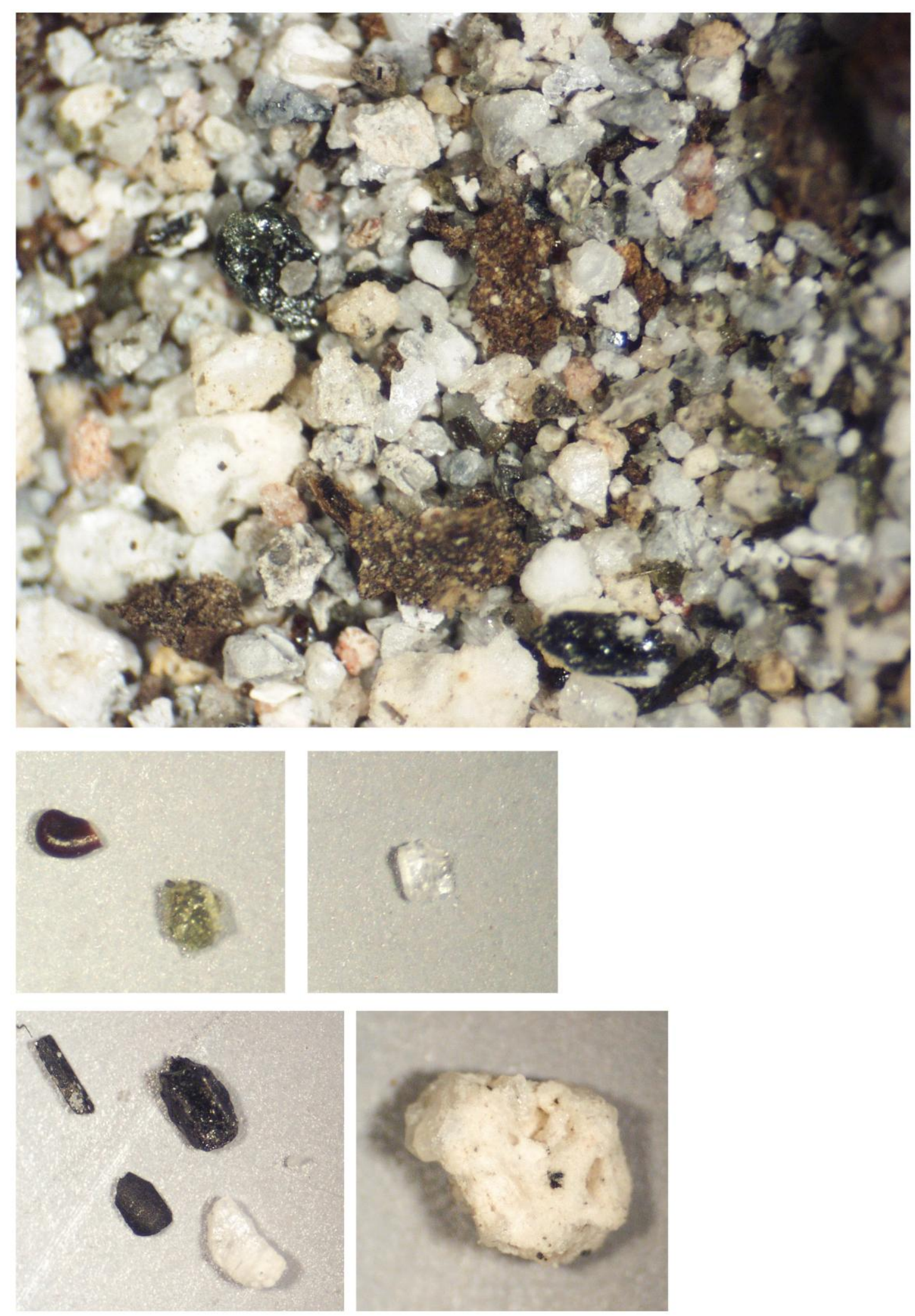

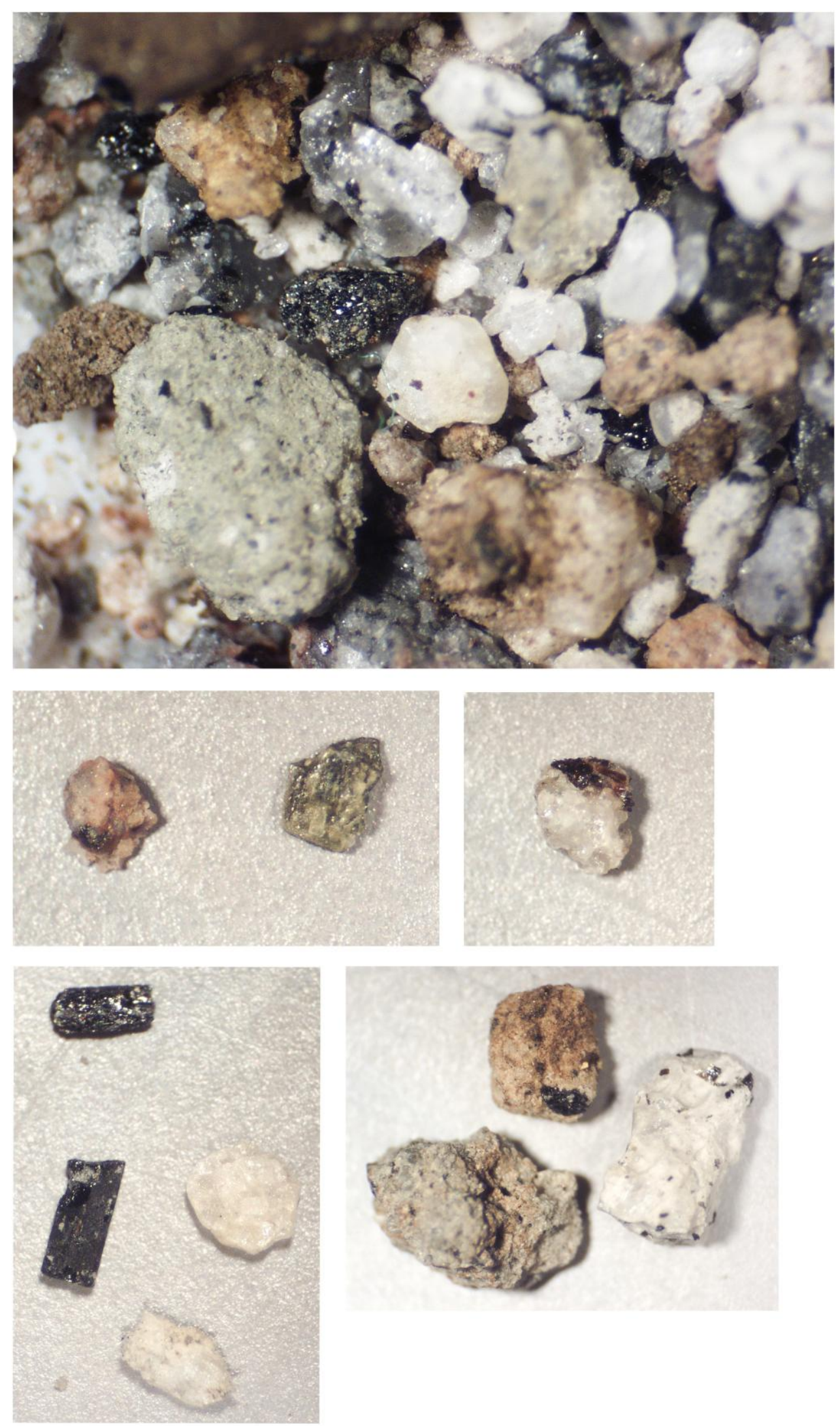

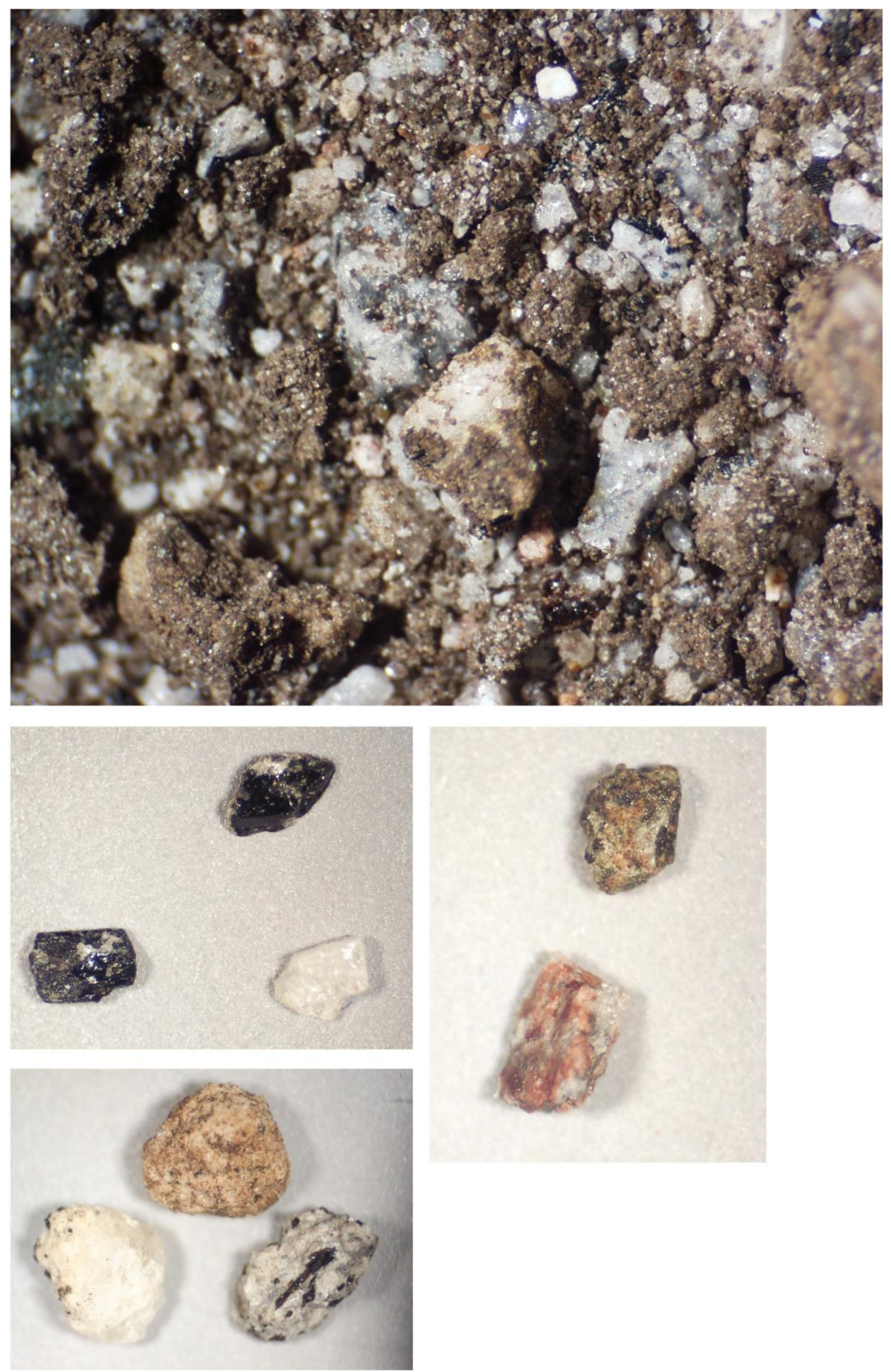


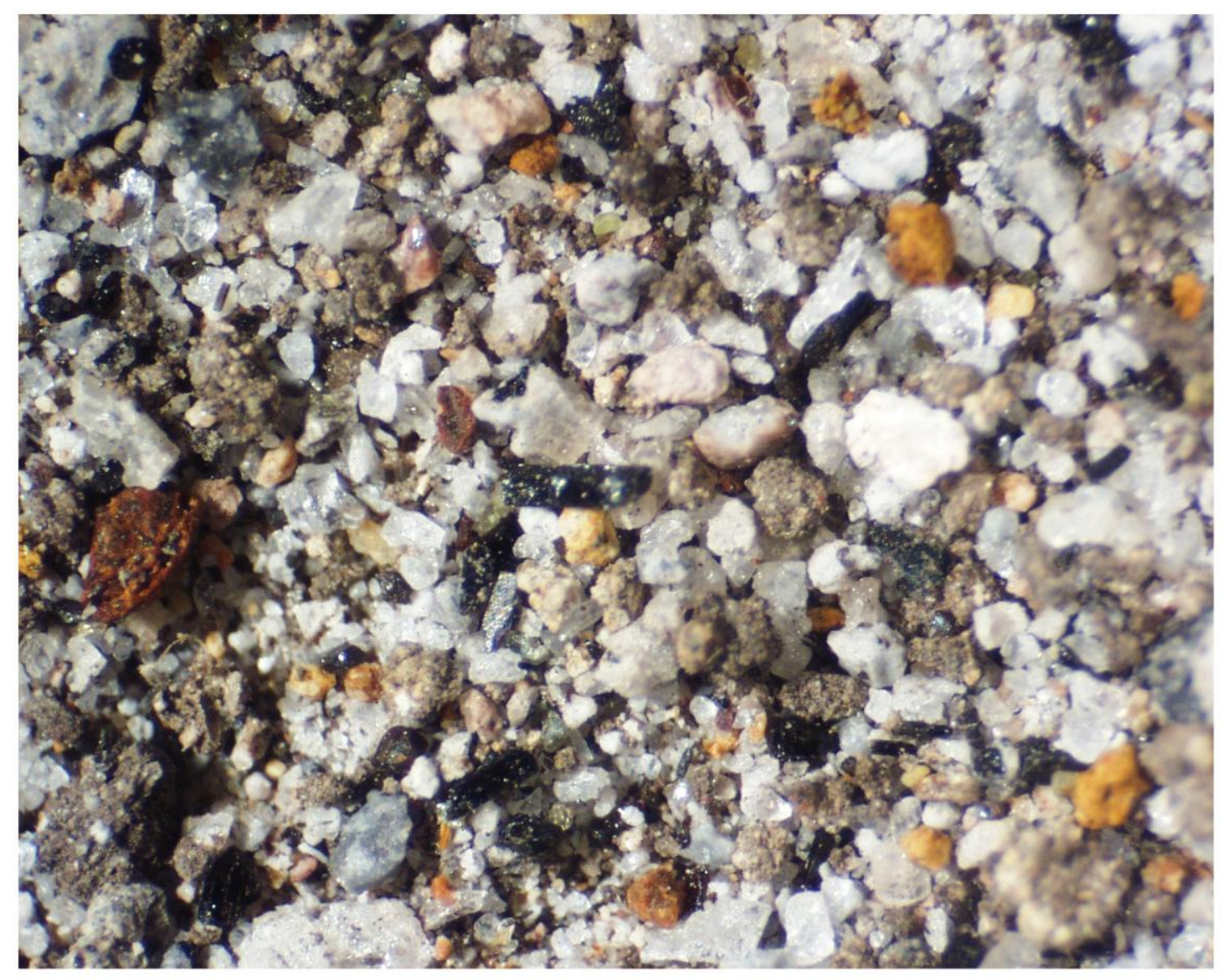

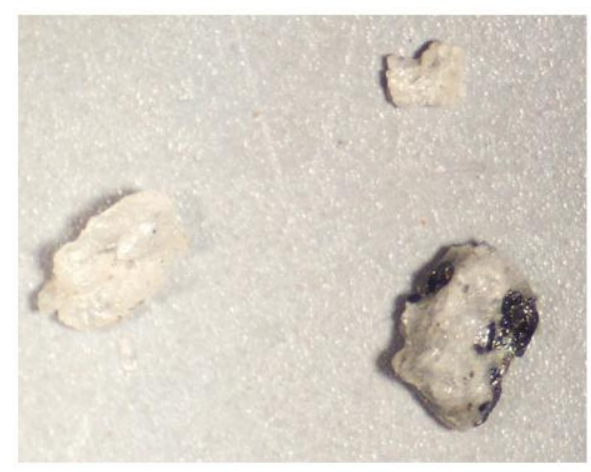

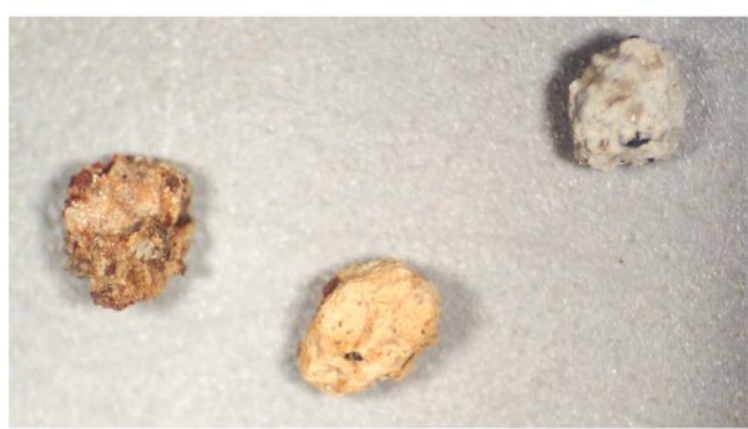

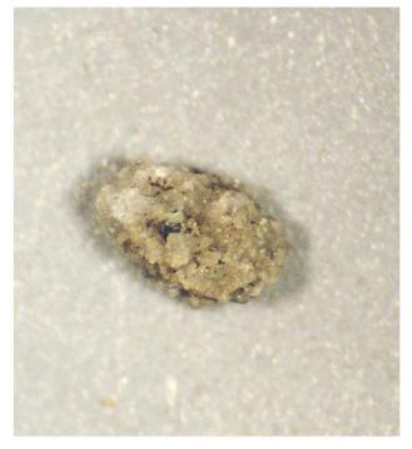
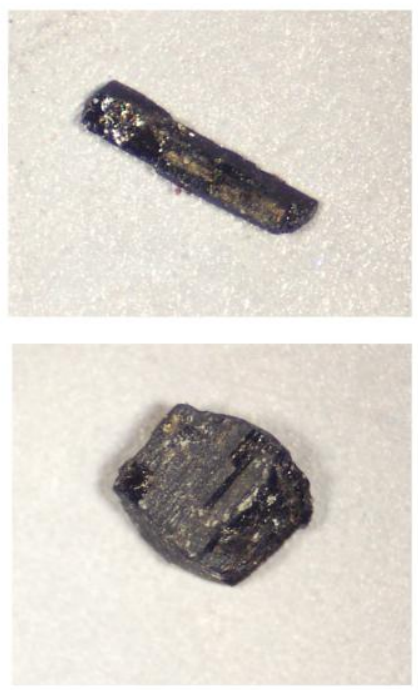


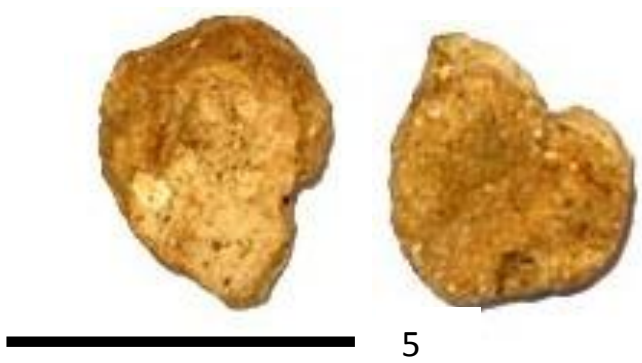

(a): tephra object from KOT (8.2)

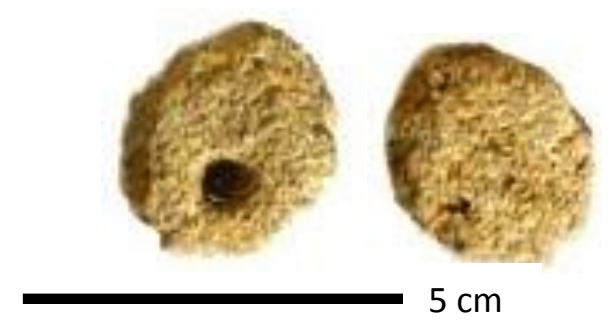

(b): tephra object from KOT B.5

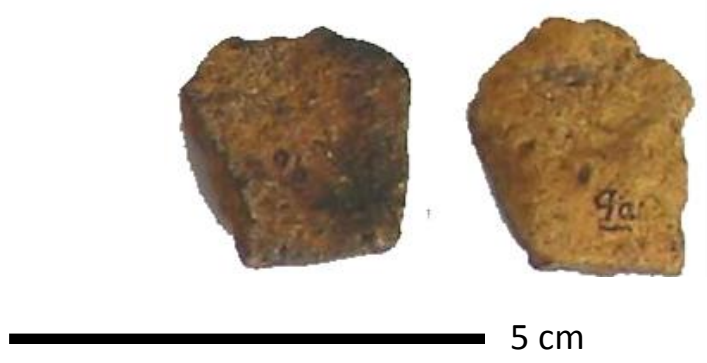

(c): tephra object from KOT D.6

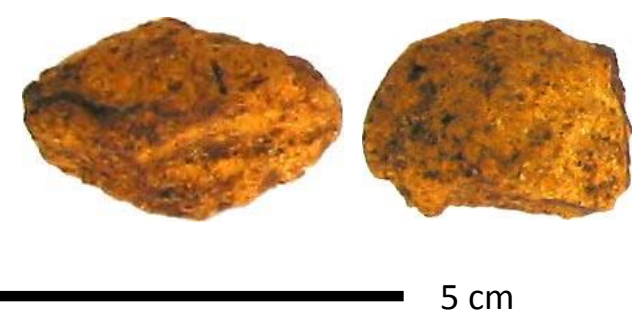

(d): tephra object from KOT G.1 


\begin{tabular}{|c|c|c|c|c|c|c|c|c|c|c|}
\hline & $\begin{array}{l}\text { Volcán } \\
\text { tephra } \\
\text { (upper) }\end{array}$ & $\begin{array}{l}\text { Volcán } \\
\text { tephra } \\
\text { (middle) }\end{array}$ & $\begin{array}{l}\text { Volcán } \\
\text { tephra } \\
\text { (lower, } \\
\text { phase 1) }\end{array}$ & $\begin{array}{l}\text { Volcán } \\
\text { tephra } \\
\text { (lower, } \\
\text { phase 2) }\end{array}$ & $\begin{array}{l}\text { Boquete } \\
\text { tephra } \\
\text { (upper, } \\
\text { phase 1) }\end{array}$ & $\begin{array}{l}\text { Boquete } \\
\text { tephra } \\
\text { (upper, } \\
\text { phase 2) }\end{array}$ & $\begin{array}{l}\text { Boquete } \\
\text { tephra } \\
\text { (middle) }\end{array}$ & $\begin{array}{l}\text { Boquete } \\
\text { tephra } \\
\text { (lower) }\end{array}$ & $\begin{array}{l}\text { Barriles } \\
\text { tephra } \\
\text { (upper) }\end{array}$ & $\begin{array}{l}\text { Barriles } \\
\text { tephra } \\
\text { (lower) }\end{array}$ \\
\hline Layer depth: & $21-42$ & $74-75.5$ & $80-84$ & $80-84$ & $8-18$ & $8-18$ & $91-92$ & $116-17$ & $20-35$ & $85-115$ \\
\hline Loose feldspar size $(\mathrm{mm}):$ & $0.5-2$ & 0.5 & 0.5 & 0.5 & 1 & 1 & 1 & 1 & $0.5-1$ & 0.5 \\
\hline Loose feldspar quantity (\%): & $40 \%$ & $40 \%$ & $50 \%$ & $40 \%$ & $40 \%$ & $30 \%$ & $50 \%$ & $30 \%$ & $30 \%$ & $40 \%$ \\
\hline Loose hornblende size $(\mathrm{mm})$ : & $0.5-2$ & 1 & 1 & 0.5 & $30 \%$ & 0.5 & 0.5 & $0.25-1$ & 1 & 0.25 \\
\hline Loose hornblende quantity $(\mathrm{mm})$ : & $30 \%$ & $30 \%$ & $25 \%$ & $30 \%$ & 1 & $25 \%$ & $25 \%$ & $25 \%$ & $15 \%$ & $30 \%$ \\
\hline Loose biotite size: & 0.5 & 1 & & & $1 \%$ & 1 & 0.5 & 1 & 1 & 1 \\
\hline Loose biotite quantity (\%): & $1 \%$ & $1 \%$ & & & & $1 \%$ & $1 \%$ & $1 \%$ & $1 \%$ & $1 \%$ \\
\hline z\% of misc crystal: & $1 \%$ & $2 \%$ & & & $5 \%$ & $1 \%$ & $2 \%$ & & & $1 \%$ \\
\hline $\begin{array}{l}\text { \% of overall sample comprised of } \\
\text { juvenile clasts: }\end{array}$ & $25 \%$ & $25 \%$ & $20 \%$ & $20 \%$ & $20 \%$ & $40 \%$ & $20 \%$ & $40 \%$ & $50 \%$ & $10 \%$ \\
\hline Juvenile fragment size $(\mathrm{mm})$ : & $1.5-6$ & $1-2$ & 1 & 0.5 & $1-4$ & $2-5$ & 1 & $3-8$ & $1-4$ & $0.25-0.75$ \\
\hline Juvenile fragment color \#1: & $\begin{array}{l}\text { Very } \\
\text { white }\end{array}$ & White & $\begin{array}{l}\text { Pure } \\
\text { white }\end{array}$ & White & $\begin{array}{l}\text { Yellow- } \\
\text { white }\end{array}$ & Yellow-white & Pure white & Orange & White & $\begin{array}{l}\text { Grayish } \\
\text { white }\end{array}$ \\
\hline $\begin{array}{l}\text { Juvenile fragment color \#2 (if bi- } \\
\text { modal): }\end{array}$ & Gray & gray & Gray & Gray & $\begin{array}{l}\text { Pure } \\
\text { white }\end{array}$ & Pure white & $\begin{array}{l}\text { Light orange- } \\
\text { gray }\end{array}$ & White & Orange & $\begin{array}{l}\text { Bright } \\
\text { orange }\end{array}$ \\
\hline $\begin{array}{l}\text { Juvenile fragment color \#3 (if tri- } \\
\text { modal): }\end{array}$ & - & - & Amber & Amber & Light gray & Orange-brown & - & gray & Gray & \\
\hline $\begin{array}{l}\text { Shape of juvenile clasts (angular, } \\
\text { rounded, sub-rounded): }\end{array}$ & $\begin{array}{l}\text { Sub- } \\
\text { angular }\end{array}$ & $\begin{array}{l}\text { Sub- } \\
\text { angular }\end{array}$ & $\begin{array}{l}\text { Sub- } \\
\text { angular }\end{array}$ & $\begin{array}{l}\text { Sub- } \\
\text { angular }\end{array}$ & $\begin{array}{l}\text { Sub- } \\
\text { angular to } \\
\text { sub- } \\
\text { rounded }\end{array}$ & Sub-angular & Sub-rounded & Sub-angular & $\begin{array}{l}\text { Sub- } \\
\text { rounded }\end{array}$ & Sub-angular \\
\hline$\%$ of vesicularity of clasts: & $25 \%$ & $15 \%$ & $15 \%$ & $15 \%$ & $20 \%$ & $15 \%$ & $10 \%$ & $15 \%$ & $20 \%$ & $10 \%$ \\
\hline Size of feldspar in juvenile clasts: & 0.75 & 0.25 & 0.25 & 0.25 & 0.5 & 1 & 0.5 & 1 & 0.5 & 0.5 \\
\hline$\%$ of feldspar in juvenile clasts: & $15 \%$ & $40 \%$ & $7 \%$ & $7 \%$ & $1 \%$ & $2 \%$ & $2 \%$ & $2 \%$ & $10 \%$ & $2 \%$ \\
\hline $\begin{array}{l}\text { Size of hornblende crystals in juvenile } \\
\text { clasts }(\mathrm{mm}) \text { : }\end{array}$ & 0.5 & 0.5 & 0.5 & 0.25 & $0.5-1$ & 1 & 0.5 & 0.5 & 0.5 & 0.25 \\
\hline $\begin{array}{l}\text { \% of hornblende crystals in juvenile } \\
\text { clasts: }\end{array}$ & $7 \%$ & $25 \%$ & $10 \%$ & $3 \%$ & $5 \%$ & $7 \%$ & $5 \%$ & $7 \%$ & $5 \%$ & $10 \%$ \\
\hline$\%$ of glass + vesicles & $78 \%$ & $35 \%$ & $83 \%$ & $90 \%$ & $94 \%$ & $91 \%$ & $93 \%$ & $91 \%$ & $85 \%$ & $88 \%$ \\
\hline $\begin{array}{l}\% \text { of sample accounted for by } \\
\text { composition categories: }\end{array}$ & $98 \%$ & $98 \%$ & $95 \%$ & $90 \%$ & $96 \%$ & $97 \%$ & $98 \%$ & $96 \%$ & $96 \%$ & $82 \%$ \\
\hline Feldspar to hornblende ratio: & 214.29 & 160 & 70 & 233 & 20 & 28.57 & 40 & 200 & 200 & 20 \\
\hline
\end{tabular}

